Atmos. Chem. Phys., 18, 10373-10389, 2018

https://doi.org/10.5194/acp-18-10373-2018

(c) Author(s) 2018. This work is distributed under

the Creative Commons Attribution 4.0 License.

\title{
The $\Delta^{17} \mathrm{O}$ and $\delta^{18} \mathrm{O}$ values of atmospheric nitrates simultaneously collected downwind of anthropogenic sources - implications for polluted air masses
}

\author{
Martine M. Savard ${ }^{1}$, Amanda S. Cole ${ }^{2}$, Robert Vet ${ }^{2}$, and Anna Smirnoff ${ }^{1}$ \\ ${ }^{1}$ Geological Survey of Canada (Natural Resources Canada), 490 de la Couronne, Québec (QC), G1K 9A9, Canada \\ ${ }^{2}$ Air Quality Research Division, Environment and Climate Change Canada, 4905 Dufferin St., \\ Toronto (ON), M3H 5T4, Canada
}

Correspondence: Martine M. Savard (martinem.savard@canada.ca)

Received: 27 November 2017 - Discussion started: 9 January 2018

Revised: 10 July 2018 - Accepted: 11 July 2018 - Published: 20 July 2018

\begin{abstract}
There are clear motivations for better understanding the atmospheric processes that transform nitrogen $(\mathrm{N})$ oxides $\left(\mathrm{NO}_{x}\right)$ emitted from anthropogenic sources into nitrates $\left(\mathrm{NO}_{3}^{-}\right)$, two of them being that $\mathrm{NO}_{3}^{-}$contributes to acidification and eutrophication of terrestrial and aquatic ecosystems, and particulate nitrate may play a role in climate dynamics. For these reasons, oxygen isotope delta values $\left(\delta^{18} \mathrm{O}\right.$, $\Delta^{17} \mathrm{O}$ ) are frequently applied to infer the chemical pathways leading to the observed mass-independent isotopic anomalies from interaction with ${ }^{17} \mathrm{O}$-rich ozone $\left(\mathrm{O}_{3}\right)$. Recent laboratory experiments suggest that the isotopic equilibrium between $\mathrm{NO}_{2}$ (the main precursor of $\mathrm{NO}_{3}^{-}$) and $\mathrm{O}_{3}$ may take long enough under certain field conditions that nitrates may be formed near emission sources with lower isotopic values than those formed further downwind. Indeed, previously published field measurements of oxygen isotopes in $\mathrm{NO}_{3}^{-}$ in precipitation $\left(w \mathrm{NO}_{3}^{-}\right)$and in particulate $\left(\mathrm{NO}_{3}^{-}\right)$samples suggest that abnormally low isotopic values might characterize polluted air masses. However, none of the air studies have deployed systems allowing collection of samples specific to anthropogenic sources in order to avoid shifts in isotopic signature due to changing wind directions, or separately characterized gaseous $\mathrm{HNO}_{3}$ with $\Delta^{17} \mathrm{O}$ values. Here we have used a wind-sector-based, multi-stage filter sampling system and precipitation collector to simultaneously sample $\mathrm{HNO}_{3}$ and $p \mathrm{NO}_{3}^{-}$, and co-collect $w \mathrm{NO}_{3}^{-}$. The nitrates are from various distances $(<1$ to $>125 \mathrm{~km})$ downwind of different anthropogenic emitters, and consequently from varying time lapses after emission.
\end{abstract}

The separate collection of nitrates shows that the $\mathrm{HNO}_{3} \delta^{18} \mathrm{O}$ ranges are distinct from those of $w$ - and $p \mathrm{NO}_{3}^{-}$. Interestingly, the $\Delta^{17} \mathrm{O}$ differences between $p \mathrm{NO}_{3}^{-}$and $\mathrm{HNO}_{3}$ shift from positive during cold sampling periods to negative during warm periods. The low $p \mathrm{NO}_{3}^{-} \Delta^{17} \mathrm{O}$ values observed during warm periods may partly derive from the involvement of ${ }^{17} \mathrm{O}$-depleted peroxy radicals $\left(\mathrm{RO}_{2}\right)$ oxidizing NO during that season. Another possibility is that nitrates derive from $\mathrm{NO}_{x}$ that has not yet reached isotopic equilibrium with $\mathrm{O}_{3}$. However, these mechanisms, individually or together, cannot explain the observed $p \mathrm{NO}_{3}$ minus $\mathrm{HNO}_{3}$ isotopic changes. We propose differences in dry depositional rates, faster for $\mathrm{HNO}_{3}$, as a mechanism for the observed shifts. Larger proportions of $\mathrm{pNO}_{3}^{-}$formed via the $\mathrm{N}_{2} \mathrm{O}_{5}$ pathway would explain the opposite fall-winter patterns. Our results show that the separate $\mathrm{HNO}_{3}, w \mathrm{NO}_{3}^{-}$and $p \mathrm{NO}_{3}^{-}$isotopic signals can be used to further our understanding of $\mathrm{NO}_{x}$ oxidation and deposition. Future research should investigate all tropospheric nitrate species as well as $\mathrm{NO}_{x}$ to refine our understanding of nitrate distribution worldwide and to develop effective emission reduction strategies.

\section{Introduction}

Anthropogenic $\mathrm{NO}_{x}\left(\mathrm{NO}\right.$ and $\left.\mathrm{NO}_{2}\right)$ emissions are oxidized to nitrate in the atmosphere in the form of gaseous, wet or particulate forms, $\mathrm{HNO}_{3}$ being one of the main precursors of $p \mathrm{NO}_{3}^{-}$. All these species may have detrimental effects on 
human health and aquatic and terrestrial ecosystems through inhalation, acidification and excess nitrogen deposition. In addition, aerosols may play a significant role in regional climate dynamics as they interact with clouds and solar radiation (e.g., IPCC, 2013). For these reasons, understanding the chemical processes controlling the transport and fate of atmospheric reactive $\mathrm{N}$ is required to help develop effective emission reduction strategies and drive climate models (in the present article, we use nitrates to collectively refer to $p \mathrm{NO}_{3}, \mathrm{HNO}_{3}$ and $w \mathrm{NO}_{3}$ ).

Triple oxygen isotopes $\left(\delta^{18} \mathrm{O}\right.$ and $\left.\Delta^{17} \mathrm{O}\right)$ have been used to decipher atmospheric oxidation pathways of $\mathrm{NO}_{x}$ leading to ambient nitrate. Michalski et al. (2003) performed the first measurement of $\Delta^{17} \mathrm{O}$ values in atmospheric nitrate. The authors found nitrate highly enriched in ${ }^{18} \mathrm{O}$ and ${ }^{17} \mathrm{O}$, likely due to the transfer of anomalous oxygen atoms from ozone $\left(\mathrm{O}_{3}\right)$ via the $\mathrm{NO}_{x}$-ozone photochemical cycle and oxidation to nitrate. During its formation, $\mathrm{O}_{3}$ inherits abnormally high $\delta^{18} \mathrm{O}$ and $\Delta^{17} \mathrm{O}$ values through mass independent fractionation. The specific $\Delta^{17} \mathrm{O}$ departure from the terrestrial mass-dependent fractionation line, named the ${ }^{17} \mathrm{O}$ anomaly, is often expressed as $\Delta^{17} \mathrm{O}=\Delta \Delta^{17} \mathrm{O}-0.517 \times \delta^{18} \mathrm{O}$ (Thiemens, 1999). Further investigations suggested that the $\delta^{18} \mathrm{O}$ and $\Delta^{17} \mathrm{O}$ values of $w \mathrm{NO}_{3}^{-}$and $p \mathrm{NO}_{3}^{-}$reflect several reactions taking place after the atmospheric emission of $\mathrm{NO}_{x}$, i.e., atmospheric oxidation pathways transforming $\mathrm{NO}_{x}$ into secondary products (Hastings et al., 2003; Michalski et al., 2003, 2004; Morin et al., 2007; Savarino et al., 2007; Alexander et al., 2009). Seasonal $\delta^{18} \mathrm{O}$ differences in $w \mathrm{NO}_{3}^{-}$samples (less variable and lower values during summer) have been interpreted to be due to changes in these chemical pathways (Hastings et al., 2003). Modelling and validation based on sparse existing data provide hope regarding a global understanding of atmospheric nitrate (Alexander et al., 2009); however, further measurements need to be done on the ground, particularly at mid-latitudes.

Additional studies dealing with triple oxygen isotope characterizations have addressed questions of methodology (Kaiser et al., 2007; Smirnoff et al., 2012), transfer of the ozone ${ }^{17} \mathrm{O}$ anomaly to atmospheric nitrate (Liang and Yung, 2007; Savarino et al., 2008; Michalski et al., 2014) or sources and chemical pathways of high (Arctic) and low (Taiwan) latitude nitrate (Morin et al., 2008; Guha et al., 2017, respectively). Triple oxygen isotope characterizations of field $\mathrm{NO}_{3}^{-}$samples are not yet widespread. Also rare are the nitrate $\delta^{18} \mathrm{O}$ and $\Delta^{17} \mathrm{O}$ values of field samples downwind from $\mathrm{NO}_{x}$-emitting sources at mid-latitudes (Kendall et al., 2007; Proemse et al., 2013). The few existing studies have chiefly characterized $w \mathrm{NO}_{3}^{-}$or the sum of $p \mathrm{NO}_{3}^{-}$and $\mathrm{HNO}_{3}$ (Michalski et al., 2004; Morin et al., 2007, 2008, 2009; Alexander et al., 2009; Proemse et al., 2012; Guha et al., 2017), and suggested these indicators would be useful to trace atmospheric nitrate in water (Kendall et al., 2007; Tsunogai et al., 2010; Dahal and Hastings, 2016), or to ap- portion the contribution of anthropogenic emissions to regional atmospheric nitrate loads (Proemse et al., 2013).

In the past, due to sampling challenges, $\mathrm{HNO}_{3}$ and $p \mathrm{NO}_{3}^{-}$ were generally collected together (without differentiation). Therefore, no studies have separately and simultaneously collected and analyzed the $\mathrm{HNO}_{3}$ and $p \mathrm{NO}_{3}^{-} \delta^{18} \mathrm{O}$ and $\Delta^{17} \mathrm{O}$ values, and discussed these isotopic characteristics of nitrate collected downwind of anthropogenic emitters. While $\mathrm{HNO}_{3}$ and $p \mathrm{NO}_{3}^{-}$can be in equilibrium (e.g., if $p \mathrm{NO}_{3}^{-}$is in the form of solid $\mathrm{NH}_{4} \mathrm{NO}_{3}$ ), this is not always the case, for example, if nitrate is bonded to calcium or dissolved in liquid water on a wet particle (see Sect. 3.3). They have different lifetimes with respect to wet scavenging (Cheng and Zhang, 2017) and dry deposition velocities (Zhang et al., 2009), and may differ in their formation pathways as well. Therefore, investigating the mass-independent and mass-dependent oxygen fractionations in nitrates collected separately may help to identify their respective formation and loss pathways, and provide additional constraints on processes controlling their distribution.

Here we have characterized nitrate collected downwind of five emission sources in central and southern Alberta, Canada, namely (1) coal-fired power plants (CFPPs), (2) city traffic, (3) chemical industries and metal refining, (4) fertilizer plant and oil refinery and (5) gas compressors plus cattle and swine feedlots. To this end, we employed wind-sectorbased active samplers to collect $\mathrm{HNO}_{3}$ and $p \mathrm{NO}_{3}^{-}$as well as $w \mathrm{NO}_{3}^{-}$downwind of the source types. The objective of this work was to assess the atmospheric $\mathrm{NO}_{x}$ reaction pathways and determine processes responsible for the distribution of $\mathrm{HNO}_{3}, w$ - and $p \mathrm{NO}_{3}^{-}$in a mid-latitudinal region.

\section{Methodology}

\subsection{Regional context}

While national reported $\mathrm{NO}_{x}$ emissions in Canada declined steadily from 2000 to 2015, emissions in the province of Alberta have remained relatively constant since 2004 (Environment and Climate Change Canada, 2016). Pioneering work was accomplished ,measuring nitrate on emitted $\mathrm{PM}_{2.5}$ (particulate matter less than $2.5 \mu \mathrm{m}$ ) and in bulk and throughfall precipitation samples (wet and some dry deposition on ion exchange resin collectors) collected at or downwind of the Athabasca oil sands mining operations in northern Alberta (Proemse et al., 2012, 2013). However, the Edmonton area in central Alberta, known to generate the highest $\mathrm{NO}_{x}$ emissions in Canada, and the area of southern Alberta, characterized by dense gas compressor station and agricultural emissions, have never been investigated.

This research project investigated nitrates $\left(p \mathrm{NO}_{3}^{-}, \mathrm{HNO}_{3}\right.$ and $w \mathrm{NO}_{3}^{-}$) from two main emission source areas: the Genesee and Edmonton areas of central Alberta, and the Vauxhall area of southern Alberta (Fig. 1a). These areas experience a continental climate, but the mean annual temperature 

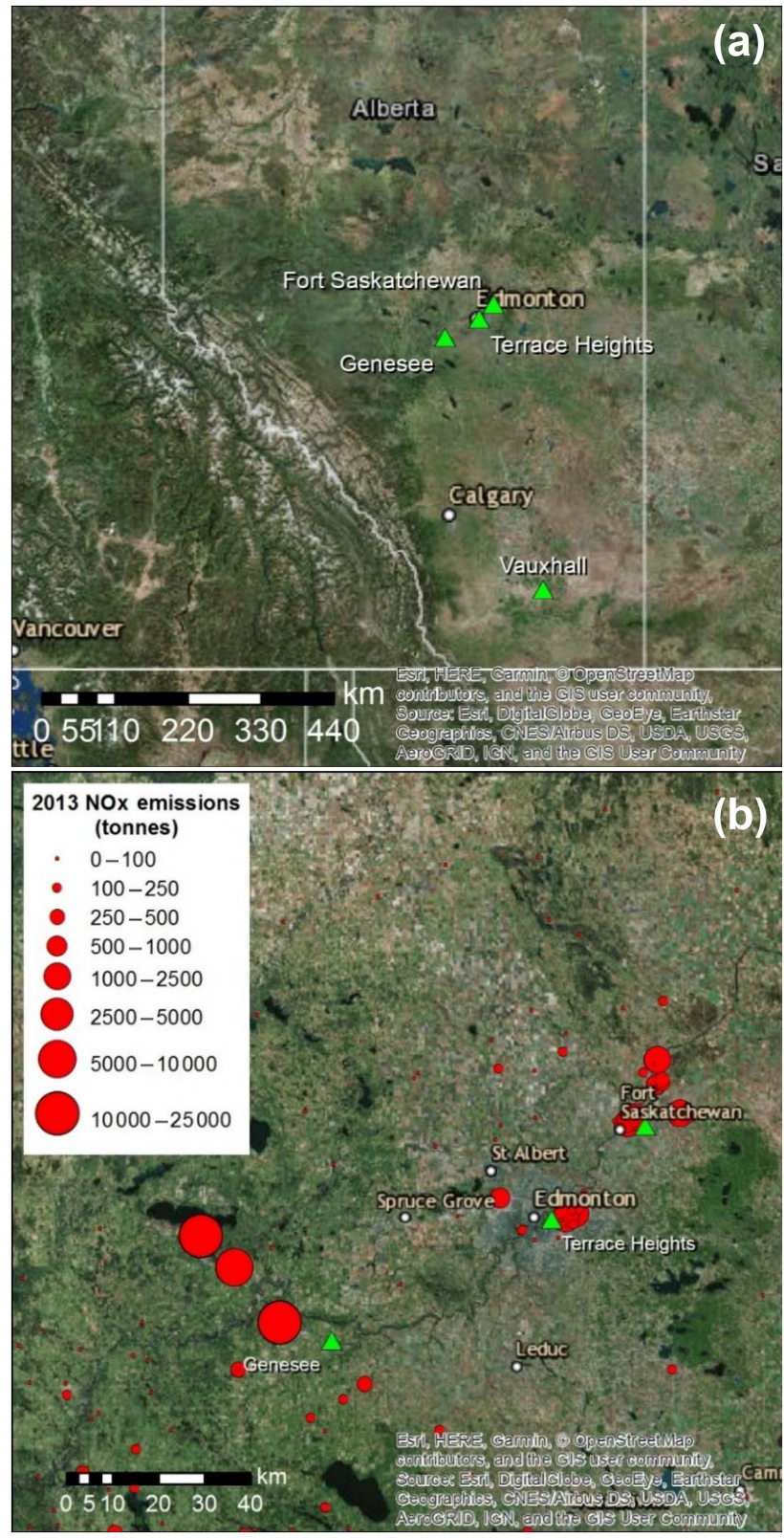

Figure 1. Aerial images showing sampling sites (green triangles) in central and southern Alberta (a), and in the greater Edmonton area (b), along with emissions of $\mathrm{NO}_{x}$ as tonnes of $\mathrm{NO}_{2}$ reported in the National Pollutant Release Inventory for 2013 (Environment and Climate Change Canada, 2018b).

at Vauxhall is slightly higher $\left(5.6^{\circ} \mathrm{C}\right)$ and total annual precipitation lower $(320 \mathrm{~mm})$ than in central Alberta $\left(3.9^{\circ} \mathrm{C}\right.$; $537 \mathrm{~mm}$; Fig. S1 in the Supplement). Fall is generally the wettest season and winter the driest. The sampling sites were at altitudes between 645 and $820 \mathrm{~m}$ (above sea level), and in continental regions devoid of the influence of marine air masses (negligible halogen oxides).
The rural Vauxhall area was selected for collecting nitrates emitted from multiple small gas compressor stations scattered throughout southern Alberta and reduced $\mathrm{N}$ from cattle and swine feedlots. The other anthropogenic emissions are from three sites in central Alberta (Fig. 1b): CFPPs at the Genesee site, $55 \mathrm{~km}$ southwest of Edmonton; trafficdominated emissions at Terrace Heights, a residential area near downtown Edmonton; and an industrial area in Fort Saskatchewan, northeast of Edmonton, where sampling two different wind sectors allowed separating different industries. In Fort Saskatchewan, sampling in the northwest sector targeted emissions from a mixture of sources of which the largest were a chemical plant and metal refinery (referred to as chemical plus metal industries; distance to sources of 3 to $7 \mathrm{~km}$ ), while the north sector point emissions were dominated by a fertilizer plant and an oil refinery (referred to as fertilizers plus oil; distance to sources from 9 to $14 \mathrm{~km}$ ). The $\mathrm{NO}_{x}$ emissions reported in the National Pollutant Release Inventory (Environment and Climate Change Canada, 2018b) for 2013 from all Alberta sources are also shown in Fig. 1.

\subsection{Sampling protocols}

Collection of nitrate samples took place between 30 September 2010 and 20 January 2014. Active air sampling was carried out using a modified version of Environment Canada's CAPMoN (Canadian Air and Precipitation Monitoring Network) sampling protocol, which is described in detail elsewhere (Sirois and Fricke, 1992). Precipitation sampling also followed CAPMoN wet-only protocols as described in the literature (Sirois and Vet, 1999). A conditional sampling method was employed to maximize the collection of nitrogen compounds from the anthropogenic sources, in which the sampling pumps and precipitation collector were activated when the site wind vane registered winds faster than $0.55 \mathrm{~m} \mathrm{~s}^{-1}\left(2 \mathrm{~km} \mathrm{~h}^{-1}\right)$ from the direction of the targeted sources. The CAPMoN sampling system was installed and operated at different sites, each at varying distances from the targeted point ( $<1$ to $35 \mathrm{~km}$ ) and diffuse sources ( 3 to $>125 \mathrm{~km}$; Table 1). Back trajectories run using the HYSPLIT model (Stein et al., 2015; Rolph, 2017) for every hour of sampling verified that the conditional sampling approach collected air masses that had primarily passed over or near the targeted source (i.e., there was no landscape feature that decoupled wind direction from back trajectories; see sample plot of back trajectories from Genesee in Fig. S2).

Ambient air was pulled through a three-stage filter pack system to collect, sequentially, particulate matter on a Teflon filter, gaseous nitric acid $\left(\mathrm{HNO}_{3}\right)$ on a Nylasorb nylon filter and gaseous ammonia on a citric acid-coated Whatman 41 filter (all $47 \mathrm{~mm}$ ). The Teflon-nylon filter method for $p \mathrm{NO}_{3}^{-}$ and $\mathrm{HNO}_{3}$ has been extensively compared and evaluated, and is currently used by national monitoring networks targeting regional background sites, CAPMoN in Canada and CASTNet (Clean Air Status and Trends Network) in the 
Table 1. Settings and conditions for wind-sector-based simultaneous sampling of atmospheric nitrates.

\begin{tabular}{|c|c|c|c|c|c|c|c|}
\hline $\begin{array}{l}\text { Site } \\
\text { (coordinates) }\end{array}$ & Sources & $\begin{array}{l}\text { Distance } \\
\mathrm{km} \text { (mean) }\end{array}$ & $\begin{array}{l}\text { Sector } \\
\text { direction; } \\
\text { opening }\end{array}$ & $\begin{array}{l}\text { Sampling } \\
\text { period; }\end{array}$ & $n$ & $\operatorname{Avg} T\left({ }^{\circ} \mathrm{C}\right)$ & Context \\
\hline $\begin{array}{l}\text { Genesee } \\
\left(114.14^{\circ} \mathrm{W},\right. \\
\left.53.31^{\circ} \mathrm{N}\right)\end{array}$ & $\begin{array}{l}\text { Coal-fired } \\
\text { power plants }\end{array}$ & $7-35$ & $\mathrm{NW}, 35^{\circ}$ & $\begin{array}{l}30 / 09 / 2010- \\
21 / 06 / 2011\end{array}$ & 6 & $\begin{array}{l}11.7,12.2 \\
5.5,-9.8 \\
-0.9,12.2\end{array}$ & 3 plants \\
\hline $\begin{array}{l}\text { Vauxhall } \\
\left(112.11^{\circ} \mathrm{W},\right. \\
\left.50.06^{\circ} \mathrm{N}\right)\end{array}$ & $\begin{array}{l}\text { Gas compres- } \\
\text { sors and cattle } \\
\text { and swine } \\
\text { feedlots }\end{array}$ & $\begin{array}{l}12-125+ \\
7.5-45+\end{array}$ & $\mathrm{W}, 65^{\circ}$ & $\begin{array}{l}25 / 10 / 2011- \\
13 / 12 / 2011\end{array}$ & 3 & $\begin{array}{l}2.6,0.7 \\
-3.5\end{array}$ & $\begin{array}{l}65+\text { compressors } \\
200+\text { feedlots }\end{array}$ \\
\hline $\begin{array}{l}\text { Terrace Heights } \\
\left(113.44^{\circ} \mathrm{W},\right. \\
\left.53.54^{\circ} \mathrm{N}\right)\end{array}$ & Urban traffic & $<1-15(4)$ & $\mathrm{W}, 150^{\circ}$ & $\begin{array}{l}24 / 07 / 2012- \\
25 / 10 / 2012\end{array}$ & 4 & $\begin{array}{l}20.3,15.6 \\
7.9,-1.8\end{array}$ & $\begin{array}{l}\text { Park in residential } \\
\text { area, } 3.5 \mathrm{~km} \text { east of } \\
\text { downtown core }\end{array}$ \\
\hline $\begin{array}{l}\text { Fort Saskatchewan } \\
\left(113.14^{\circ} \mathrm{W}\right. \\
\left.53.72^{\circ} \mathrm{N}\right)\end{array}$ & $\begin{array}{l}\text { Chemical } \\
\text { industries and } \\
\text { metal refining }\end{array}$ & $3-7(4)$ & $\mathrm{NW}, 88^{\circ}$ & $\begin{array}{l}\text { 12/04/2013- } \\
06 / 09 / 2013\end{array}$ & 4 & $\begin{array}{l}4.3,15.7 \\
16.3,17.7\end{array}$ & $\begin{array}{l}\text { Chemical plant } \\
\text { and metal refi- } \\
\text { nery largest } \mathrm{NO}_{x} \\
\text { sources; fertilizer } \\
\text { plant largest } \mathrm{NH}_{3} \\
\text { source }\end{array}$ \\
\hline $\begin{array}{l}\text { Fort Saskatchewan } \\
\left(113.14^{\circ} \mathrm{W}\right. \\
\left.53.72^{\circ} \mathrm{N}\right)\end{array}$ & $\begin{array}{l}\text { Fertilizer plant } \\
\text { and oil refinery }\end{array}$ & 9-14 (11) & $\mathrm{N}, 27^{\circ}$ & $\begin{array}{l}20 / 09 / 2013- \\
20 / 01 / 2014\end{array}$ & 1 & -8.1 & $\begin{array}{l}\text { Fertilizer plant } \\
\text { largest } \mathrm{NH}_{3} \text { and } \\
\mathrm{NO}_{x} \text { source, oil } \\
\text { refinery major } \mathrm{NO}_{x} \\
\text { source }\end{array}$ \\
\hline
\end{tabular}

$n$ : number of sampling sessions. Avg $T$ : average temperature during each of the consecutive sampling sessions.

United States. Previous testing showed negligible collection of $\mathrm{HNO}_{3}$ on the Teflon filter, $<3 \%$ breakthrough of $\mathrm{HNO}_{3}$ from the nylon filter with loadings more than 3 times higher than reported here and blanks for $\mathrm{pNO}_{3}^{-}$and $\mathrm{HNO}_{3}$ of approximately $0.2 \mu \mathrm{g} \mathrm{N}$ per filter (Anlauf et al., 1985, 1986). Intercomparisons with more labour-intensive methods, such as tunable diode laser absorption spectroscopy and annular denuder-filter pack systems, have shown evidence of some volatilization of ammonium nitrate from the Teflon filter, leading to a negative bias in $\mathrm{pNO}_{3}^{-}$and positive bias in $\mathrm{HNO}_{3}$ under hot $\left(>25^{\circ} \mathrm{C}\right)$ and dry conditions, particularly in high ambient concentrations (e.g., Appel et al., 1981). However, other field studies have shown no significant differences in $\mathrm{HNO}_{3}$ between filter packs and denuder and/or TDLAS systems (Anlauf et al., 1986; Sickles Ii et al., 1990) or mixed results (Spicer et al., 1982; Zhang et al., 2009). While those studies used short-duration sampling, a comparison for weekly samples at a lower concentration site showed good agreement between filter pack and denuder values for most of the study but potential interference from $\mathrm{HNO}_{2}$ (nitrous acid) on the nylon filter in two samples (Sickles Ii et al., 1999). Based on the conditions in Alberta, we estimate that there is little or no volatilization of $\mathrm{NH}_{4} \mathrm{NO}_{3}$ for samples with mean temperatures below $5^{\circ} \mathrm{C}$, but there is a possibility for nitrate loss of up to $30 \%$ in the warmest sampling periods.
After the first five sample periods, an experimental active sampling system for $\mathrm{NO}_{2}$ and $\mathrm{NO}_{x}$ was added downstream of the three-stage filter pack. This system consisted of one or two custom cartridges packed with Maxxam Analytics' resin to selectively collect $\mathrm{NO}_{2}$, and one- or two-stage filter packs containing two identical Maxxam Analytics' impregnated filters designed to collect $\mathrm{NO}_{x}$ (mostly $\mathrm{NO}$ due to upstream collection of $\mathrm{NO}_{2}$ ). Oxygen isotopes in $\mathrm{NO}_{2}$ and $\mathrm{NO}_{x}$ were not measured since we could not rule out oxygen isotope exchange during the extraction process; however, concentrations meeting the quality control (QC) criteria (Savard et al., 2017) are presented for reference in Table S1.

Here we report on oxygen isotopes in the simultaneously sampled $\mathrm{HNO}_{3}$ and $p \mathrm{NO}_{3}^{-}$, along with co-sampled $w \mathrm{NO}_{3}^{-}$ in rain and snow samples. Note that precipitation events did not occur regularly (see Fig. S1), so that the number of aqueous samples collected was fewer than the gas and particulate samples. Both the air and precipitation samplers were only active when the wind direction was from the desired source sector and the wind speed was greater than $0.55 \mathrm{~m} \mathrm{~s}^{-1}$ $\left(2 \mathrm{~km} \mathrm{~h}^{-1}\right)$. Four identical air sampling systems operated simultaneously at each site, with samples pooled when necessary to provide sufficient filter loadings for isotope analysis and, when possible, measured separately to estimate sampling precision. In contrast to the four gas-particle sam- 
pling systems, there was a single precipitation collector at each site, and therefore external precision was not determined for precipitation samples. Individual sample deployment times ranged from 5 to 113 days, and total air sampling time within the wind direction sectors ranged from 21 to $360 \mathrm{~h}$ (Table S1). The variable cumulative periods reflected the frequency of the wind flow from the targeted source sectors and the amount of time required to obtain sufficient mass loadings on the filters.

Two or three replicate samples for most species were pooled at Genesee and Vauxhall, the first two sampling sites, subject to the requirement that sampled air volumes be within $15 \%$ of each other, thereby eliminating samples that experienced flow problems. Flow issues were primarily due to pump failure, likely caused by cycling the pumps on and off frequently in early samples. Therefore, for later samples the protocol was changed such that the pumps remained on and valves were used to switch the pumps between sampling lines and non-sampling tubing based on the wind sector. At the sites sampled later in the Edmonton area, improvements to the laboratory analytical procedure allowed for smaller sample amounts and eliminated the need for sample pooling.

\subsection{Analytical procedures}

Nitric acid from nylon filters was extracted using $10 \mathrm{~mL}$ of $0.01 \mathrm{M}$ solution of $\mathrm{NaCl}$. Particulate $\mathrm{NO}_{3}$ from Teflon filters was extracted in two portions of $6 \mathrm{~mL}$ of ultrapure water (ELGA). To reduce possible evaporation, filters were placed in an ultrasonic bath with ice. The extractions were performed during $1 \mathrm{~h}$ and samples were left for $48 \mathrm{~h}$ in a fridge to insure the complete extractions. The solutions were decanted and a small portion $(1-2 \mathrm{~mL})$ was used to determine concentrations. The remaining extracts were stored in the fridge for subsequent isotope analysis. The blanks from both filters were treated the same way.

Concentration of nitrates in Teflon and Nylon filter extracts and in precipitation samples were determined at the Institut national de la recherche scientifique - Eau, Terre, Environnement (INRS-ETE). The determinations used an automated QuikChem 8000 FIA+ analyzer (Lachat Instruments), equipped with an ASX-260 series autosampler. The detection limit for the method with sulfanilamide (31-107-04-1-A) was $0.03 \mu \mathrm{mol} \mathrm{L}^{-1}$ of $\mathrm{NO}_{3}^{-}-\mathrm{N}$. Nitrite concentrations were also measured in the extracts. Nitrite concentrations above the detection limit $\left(1.1 \mu \mathrm{mol} \mathrm{L}-1\right.$ of $\left.\mathrm{NO}_{2}^{-}-\mathrm{N}\right)$ were found in a handful of samples at Terrace Heights. These samples were excluded from the reported data.

We characterized the $\Delta^{17} \mathrm{O}, \delta^{18} \mathrm{O}$ and $\delta^{15} \mathrm{~N}$ ratios of $\mathrm{HNO}_{3}, w \mathrm{NO}_{3}^{-}$and $p \mathrm{NO}_{3}^{-}$, along with the $\delta^{15} \mathrm{~N}$ values of $\mathrm{NH}_{3}, w \mathrm{NH}_{4}, p \mathrm{NH}_{4}$ and $\mathrm{NO}_{x}$ (all $\mathrm{N}$ isotopic results are in Savard et al., 2017). The present article deals solely with the $\delta^{18} \mathrm{O}$ and $\Delta{ }^{17} \mathrm{O}$ values obtained for the three nitrate species. We treated the samples using the chemical conversion and thermal decomposition of $\mathrm{N}_{2} \mathrm{O}$ protocols, providing the abil-
Table 2. Isotopic reproducibility (modified median absolute deviation) established using two to four parallel active CAPMoN sampling set-ups in seven separate sampling periods, resulting in $(n)$ total samples.

\begin{tabular}{lrr}
\hline $\mathrm{N}$ compound $(n)$ & $\delta^{18} \mathrm{O} / \% 0$ & $\Delta^{17} \mathrm{O} / \% 0$ \\
\hline $\begin{array}{l}\text { Teflon filters } \\
p \mathrm{NO}_{3}^{-}(19)\end{array}$ & 2 & 1 \\
\hline $\begin{array}{l}\mathrm{Nylon} \text { filters } \\
\mathrm{HNO}_{3}(18)\end{array}$ & 1 & 0.7 \\
\hline
\end{tabular}

ity to simultaneously analyze low-concentration $\mathrm{N}$ - and Ocontaining species (Smirnoff et al., 2012).

A notable challenge in the analysis of the filter-based atmospheric samples is their small extraction volumes. Only $10-12 \mathrm{~mL}$ of extract solution was normally available for the measurement of concentrations and isotopic analysis. In addition, the concentrations of these low volume samples were also low (7.1-21.4 $\mu \mathrm{mol} \mathrm{L}^{-1}$ of $\left.\mathrm{NO}_{3}^{-}-\mathrm{N}\right)$. Therefore, not all samples could be diluted to produce volumes sufficient for reduction of $\mathrm{NO}_{3}^{-}$to $\mathrm{NO}_{2}$ and subsequent conversion to $\mathrm{N}_{2} \mathrm{O}$, the final product before isotope analysis. Samples with an initial concentration below $2.3 \mu \mathrm{mol} \mathrm{L}{ }^{-1}$ could not be treated individually and were combined to produce volumes sufficient for analyses (same sampling period but combination of collected parallel samples).

The preparation steps involved conversion of nitratecontaining samples into nitrite $\left(\mathrm{NO}_{2}^{-}\right)$using a custom-made cadmium column. The final preparation step involved using sodium azide to ultimately produce $\mathrm{N}_{2} \mathrm{O}$ (McIlvin and Altabet, 2005; Smirnoff et al., 2012). All extracted $\mathrm{N}_{2} \mathrm{O}$ was analyzed using a pre-concentrator (PreCon, Thermo Finnigan MAT) including a furnace with "gold" wires, online with an isotope ratio mass spectrometer (Delta V Plus, Thermo Electron; Kaiser et al., 2007; Smirnoff et al., 2012). The utilized approach allows the spectrum of $\delta^{15} \mathrm{~N}, \Delta^{17} \mathrm{O}$ and $\delta^{18} \mathrm{O}$ values from O-bearing $\mathrm{N}$-species to be determined in samples containing as little as $37.5 \mathrm{nmol}$ of $\mathrm{N}(15 \mathrm{~mL}$ final solution). Extracts from filter blanks were processed in the same way. The blanks from nylon filters were not detectable. Peak heights from the blanks resulting from Teflon filters were detected and always below $10 \%$ of sample peaks, having a negligible effect (within the analytical precision). The USGS34, USGS-35 and USGS-32 nitrate reference materials were used and processed exactly the same way as the samples, i.e., converted from nitrate to nitrite, then to $\mathrm{N}_{2} \mathrm{O}$. The laboratory analytical precision (average of replicates) determined during the present study was $0.6 \%$ for $\delta^{18} \mathrm{O}$ and $\Delta^{17} \mathrm{O}$ values in gaseous $(n=12)$ and solid nitrates $(n=20)$. For $w \mathrm{NO}_{3}$, analytical replicates gave $0.6 \%$ and $0.5 \%$, for $\delta^{18} \mathrm{O}(n=3)$ and $\Delta{ }^{17} \mathrm{O}(n=4)$ values, respectively. The $\Delta^{17} \mathrm{O}$ values are defined as $\ln \left(1+\delta^{17} \mathrm{O}\right)-0.516 \times \ln \left(1+\delta^{18} \mathrm{O}\right)$, relative to $\mathrm{Vi}$ enna Standard Mean Ocean Water (VSMOW). 


\section{Results and interpretation}

\subsection{Isotopic reproducibility when using the CAPMoN filter pack sampling system}

Data obtained from at least two of the four identical CAPMoN sample collection streams at each sampling site were used to calculate the reproducibility of each isotopic value measured. With four or fewer samples collected during each sampling period, a non-parametric approach was deemed most appropriate. Therefore, for each of the 18 sampling periods a median isotopic value was calculated, then the 2 to 4 absolute deviations from this median were calculated (Tables 2, S1). Although there were 4 replicates in 18 periods, the pooling of simultaneously collected samples and the QC steps described earlier reduced the total number of replicates for each compound (Table 3). The median absolute deviation (MAD) for each compound was then calculated from the 15-38 absolute deviations. Finally, for comparability with the more familiar standard deviation, the MAD was scaled using the standard 0.6745 divisor to give the modified median absolute deviation (M.MAD), a scaled parameter that will be equal to the standard deviation in the event of which the distribution is Gaussian (Randles and Wolfe, 1979; Sirois and Vet, 1999). This suite of parallel tests indicates that all measured species show coherent and reproducible $\Delta^{17} \mathrm{O}$ and $\delta^{18} \mathrm{O}$ results, with the M.MAD varying between $0.7 \%$ and $2 \%$ (Table 2). These estimations encompass the precision of the entire method, including errors due to sampling, chemical treatments and instrumental analysis.

A potential complication of the air sampling method can arise if there was significant volatilization of $\mathrm{NH}_{4} \mathrm{NO}_{3}$ on the particle filter into $\mathrm{HNO}_{3}$ and $\mathrm{NH}_{3}$, with subsequent collection on the downstream gas filters. This could result in equilibrium isotopic fractionation between the particle and gaseous components, which would become artificially high and low, respectively, with more fractionation at higher temperatures (summer) relative to lower temperatures (winter) when volatilization is minimal (Keck and Wittmaack, 2005). We find the $p \mathrm{NO}_{3}^{-}$isotopic values $\left(\Delta^{17} \mathrm{O}\right.$ and $\left.\delta^{18} \mathrm{O}\right)$ to be generally higher during winter than during summer (see Sect. 3.4). Moreover, the $p \mathrm{NO}_{3}^{-} \delta^{18} \mathrm{O}$ minus $\mathrm{HNO}_{3} \delta^{18} \mathrm{O}$ differences are negative during summer (see Sect. 3.6), opposite to the expected isotopic artefact if particulate volatilization were the dominant factor in determining the particle-gas isotopic differences (the same was concluded for the $\delta^{15} \mathrm{~N}$ values in $\mathrm{NH}_{3}$ and $\mathrm{NH}_{4}$; Savard et al., 2017). We therefore conclude that, while volatilization may occur in the summer samples, other isotope effects must be larger in order to lead to the observed differences. In addition, volatilization would cause mass-dependent fractionation and would not affect the ${ }^{17} \mathrm{O}$ anomaly; therefore, $\Delta^{17} \mathrm{O}$ values remain robust indicators of chemical pathways in this situation. Finding that the sampling protocols are adequate for isotopic work is in agreement with a previous study using a comparable method that found minimal fractionation for $\mathrm{pNO}_{3}^{-}$and $\mathrm{HNO}_{3}$ (Elliott et al., 2009).

\subsection{Concentrations and isotopic ratios of nitrates in Alberta samples}

The range of $\mathrm{HNO}_{3}-\mathrm{N}$ concentrations measured by the filters (from 0.01 to $0.15 \mu \mathrm{g} \mathrm{m}^{-3}$; average of 0.06 ) is slightly lower than that of $p \mathrm{NO}_{3}^{-}-\mathrm{N}$ (from 0.02 to $0.35 \mu \mathrm{g} \mathrm{m}^{-3}$; average of 0.12). For context, the median concentrations at all CAPMoN sites, which represent non-urban areas across Canada, range from 0.02 to $0.25 \mu \mathrm{g} \mathrm{m}^{-3}$ for $\mathrm{HNO}_{3}-\mathrm{N}$ and from 0.007 to $0.45 \mu \mathrm{g} \mathrm{m}^{-3}$ for $p \mathrm{NO}_{3}^{-}-\mathrm{N}$ (Cheng and Zhang, 2017), with the higher values at sites affected by regional and transboundary pollution. Background sites for this region are sparse, but concentrations at Cree Lake in neighbouring Saskatchewan were the lowest in Canada reported up to 2011 (Cheng and Zhang, 2017), and 2014-2016 measurements at Wood Buffalo National Park on the northern Alberta border revealed similar average concentrations of $0.02 \mu \mathrm{g} \mathrm{m}^{-3}$ of $\mathrm{NO}_{3}^{-}-\mathrm{N}$ for both $\mathrm{HNO}_{3}$ and $\mathrm{pNO}_{3}^{-}$(preliminary internal data). Therefore, the lowest concentrations in our samples approached average background concentrations, while the highest were 20 or more times higher than the regional background. The range of $\mathrm{NO}_{3}^{-}-\mathrm{N}$ concentrations of the $w \mathrm{NO}_{3}^{-}$samples was $10.71-34.29 \mu \mathrm{mol} \mathrm{L}^{-1}$. For comparison, volume-weighted mean annual concentrations of nitrate at the remote CAPMoN site to the north (Snare Rapids) for 2011-2014 were approximately $5.00 \mu \mathrm{mol} \mathrm{L}^{-1}$ of $\mathrm{NO}_{3}^{-}-\mathrm{N}$, while at the most polluted site in southern Ontario (Longwoods) the volume-weighted mean concentration was approximately $21.43 \mu \mathrm{mol} \mathrm{L}^{-1}$ (Environment and Climate Change Canada, 2018a). It should be pointed out that precipitation ion concentrations vary significantly with precipitation amount, so the short samples collected here are not necessarily representative of annual volume-weighted means.

The average $\delta^{18} \mathrm{O}$ and $\Delta^{17} \mathrm{O}$ values of $\mathrm{HNO}_{3}$ (gas), $w$ - and $p \mathrm{NO}_{3}^{-}$show no apparent systematic ordering (Tables 3, S1 and S2), in contrast to what was found for $\delta^{15} \mathrm{~N}$ values in the same samples (Savard et al., 2017). As expected, there is no systematic tendency when looking at the samples collected from the anthropogenic sources: CFPPs $\mathrm{HNO}_{3}$ and $p \mathrm{NO}_{3}^{-}$have the highest $\delta^{18} \mathrm{O}$ and $\Delta^{17} \mathrm{O}$ averages, but not the highest delta values for $w \mathrm{NO}_{3}^{-}$values; chemical industries show the lowest $\delta^{18} \mathrm{O}$ and $\Delta^{17} \mathrm{O}$ averages for $w$ - and $p \mathrm{NO}_{3}$, but not for $\mathrm{HNO}_{3}$. Though the number of samples was limited, $w \mathrm{NO}_{3}^{-} \Delta^{17} \mathrm{O}$ values were roughly correlated with the weighted average $\Delta^{17} \mathrm{O}$ values of $p \mathrm{NO}_{3}$ and $\mathrm{HNO}_{3}$ in samples covering the same time periods, consistent with scavenging of both $\mathrm{HNO}_{3}$ and $p \mathrm{NO}_{3}$ by wet deposition. This observation indicates that the oxygen isotopes in the three nitrate species are not predominantly source dependent (see also Fig. S3), as previously suggested in the literature (Michalski et al., 2003). 
Table 3. Average oxygen isotopic ratios for $\mathrm{NO}_{3}^{-}$sampled as gas $\left(\mathrm{HNO}_{3}\right), w$ (precipitation) and $p$ (particulate matter) relative to VSMOW.

\begin{tabular}{|c|c|c|c|c|c|c|}
\hline \multirow{2}{*}{$\begin{array}{l}\text { Matrix } \\
\text { source }\end{array}$} & Gas & $w$ & \multirow[t]{2}{*}{$p$} & \multicolumn{3}{|l|}{ Gas } \\
\hline & \multicolumn{2}{|c|}{$\delta^{18} \mathrm{O} / \%$ o } & & \multicolumn{3}{|c|}{$\Delta^{17} \mathrm{O} / \%$ o } \\
\hline Coal-fired power plants & $\begin{array}{r}69.7 \\
(5)\end{array}$ & $\begin{array}{r}66.1 \\
(4)\end{array}$ & $\begin{array}{r}70.7 \\
(4)\end{array}$ & $\begin{array}{r}25.1 \\
(5)\end{array}$ & $\begin{array}{r}25.4 \\
(4)\end{array}$ & $\begin{array}{r}26.6 \\
(4)\end{array}$ \\
\hline Fertilizers plant and oil refinery & $\begin{array}{r}63.2 \\
(1)\end{array}$ & $\begin{array}{r}71.4 \\
(1)\end{array}$ & $\begin{array}{r}69.5 \\
(1)\end{array}$ & $\begin{array}{r}19.3 \\
(1)\end{array}$ & $\begin{array}{r}26.0 \\
(1)\end{array}$ & $\begin{array}{r}23.8 \\
(1)\end{array}$ \\
\hline Chemical industries and metal refining & $\begin{array}{r}65.7 \\
(4)\end{array}$ & $\begin{array}{r}61.9 \\
(2)\end{array}$ & $\begin{array}{r}54.6 \\
(4)\end{array}$ & $\begin{array}{r}21.8 \\
(4)\end{array}$ & $\begin{array}{r}21.4 \\
(2)\end{array}$ & $\begin{array}{r}18.5 \\
(4)\end{array}$ \\
\hline Gas compressors & $\begin{array}{r}65.0 \\
(2)\end{array}$ & - & $\begin{array}{r}63.1 \\
(3)\end{array}$ & $\begin{array}{r}24.5 \\
(2)\end{array}$ & - & $\begin{array}{r}26.4 \\
(3)\end{array}$ \\
\hline City traffic & $\begin{array}{r}65.7 \\
(3)\end{array}$ & $\begin{array}{r}67.2 \\
(2)\end{array}$ & $\begin{array}{r}59.6 \\
(3)\end{array}$ & $\begin{array}{r}21.2 \\
(3)\end{array}$ & $\begin{array}{r}24.4 \\
(2)\end{array}$ & $\begin{array}{r}22.5 \\
(3)\end{array}$ \\
\hline Mean & 66.8 & 66.0 & 62.6 & 23.0 & 24.3 & 23.4 \\
\hline
\end{tabular}

(n): number of sampling periods characterized.

Table 4. Compilation of triple oxygen isotopic ranges obtained for atmospheric and emitted nitrates.

\begin{tabular}{|c|c|c|c|c|}
\hline$\delta^{18} \mathrm{O} / \%$ & $\Delta^{17} \mathrm{O} / \%$ & Regional context & Location & Authors \\
\hline \multicolumn{5}{|l|}{$\mathrm{HNO}_{3}$} \\
\hline $62.4-81.7$ & $19.3-29.0$ & Various contaminated sites & Alberta, Canada & This study \\
\hline \multicolumn{5}{|l|}{$p \mathrm{NO}_{3}^{-}$} \\
\hline $43-62$ & $20-27$ & Coast, Trinidad Head & California, USA & Patris et al. (2007) \\
\hline $78-92$ & $29.8-35.0$ & High Arctic (Alert, Ellesmere Is.) & Nunavut, Canada & Morin et al. (2007) \\
\hline $62-112$ & $19-43$ & Coast & Antarctica & Savarino et al. (2007) \\
\hline $15.6-36.0$ & -0.2 to 1.8 & Oil sands mining stacks, $\mathrm{PM}_{2.5}$ & Alberta, Canada & Proemse et al. (2012) \\
\hline $49-86$ & $19-27$ & Coast (onboard sampling) & California, USA & Vicars et al. (2013) \\
\hline $10.8-92.4$ & $2.7-31.4$ & Mt. Lulin, partly polluted air masses & Central Taiwan & Guha et al. (2017) \\
\hline $48.4-83.2$ & $13.8-30.5$ & Various contaminated sites & Alberta, Canada & This study \\
\hline \multicolumn{5}{|l|}{$w \mathrm{NO}_{3}^{-}$} \\
\hline $66.3-84.0$ & $20.2-36.0$ & Shenandoah National Park & Virginia, USA & Coplen et al. (2004) \\
\hline $70-90$ & $20-30$ & Bimonthly sampling across state & New England, USA & Kendall et al. (2007) \\
\hline $68-101$ & $20.8-34.5$ & Rishiri Island, polluted air masses & Northern Japan & Tsunogai et al. (2010) \\
\hline $51.7-72.8$ & $18.9-28.1$ & Highway traffic emissions & Ontario, Canada & Smirnoff et al. (2012) \\
\hline $35.0-80.7$ & $15.7-32.0$ & Oil sands mining (with some dry dep.) & Alberta, Canada & Proemse et al. (2013) \\
\hline $57.4-74.4$ & $19.2-30.1$ & Various contaminated sites & Alberta, Canada & This study \\
\hline \multicolumn{5}{|c|}{ Undifferentiated and bulk $\mathrm{NO}_{3}^{-}$} \\
\hline $60-95$ & $21-29$ & Polluted coastal area \& Remote land & California, USA & Michalski et al. (2004) \\
\hline $57-79$ & $22-32$ & High Arctic & Nunavut, Canada & Morin et al. (2008) \\
\hline $36-105$ & $13-37$ & Marine boundary layer & $65^{\circ} \mathrm{S}$ to $79^{\circ} \mathrm{N}$ Atlantic & Morin et al. (2009) \\
\hline $56.6-82.3^{*}$ & $16.7-30.2^{*}$ & Various contaminated sites & Alberta, Canada & This study \\
\hline
\end{tabular}

Note: isotopic values rounded to the whole number are from published graphs (except for precise O values in Morin et al., 2007). * Calculated using weighted averages of $\mathrm{HNO}_{3}$ and $\mathrm{pNO}_{3}$ isotopic results.

Considering all nitrate species, the Alberta $\delta^{18} \mathrm{O}$ and $\Delta^{17} \mathrm{O}$ values range between +48.4 and $+83.2 \%$, and between $13.8 \%$ and $30.5 \%$, respectively (Tables 4 , S1, Fig. S4). These ranges indicate that ozone partly transferred its isotopic anomaly to nitrates during $\mathrm{NO}_{x}$ cycling and oxida- tion (nitrate derived through combustion in $\mathrm{O}_{2}$ would show $\delta^{18} \mathrm{O}$ and $\Delta^{17} \mathrm{O}$ values of $23.5 \%$ and $0 \%$, respectively). When examining the existing $\delta^{18} \mathrm{O}$ and $\Delta^{17} \mathrm{O}$ data for $w$ and $p \mathrm{NO}_{3}^{-}$in the literature, the ranges for our mid-latitude samples are within those previously reported (Table 4). The 

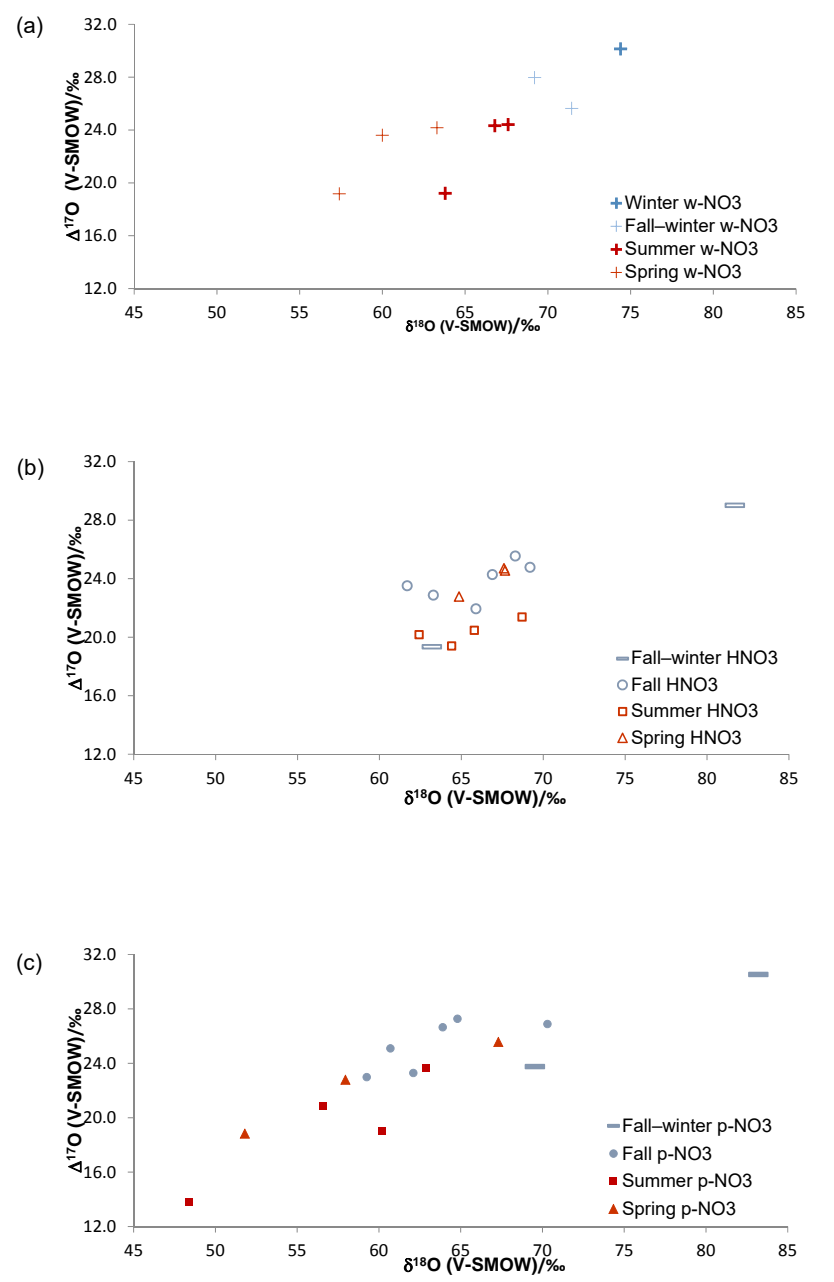

Figure 2. Triple $\mathrm{O}$ isotopic results obtained for simultaneously collected atmospheric $\mathrm{HNO}_{3}$ (a), $w \mathrm{NO}_{3}^{-}$(b) and $\mathrm{pNO}_{3}^{-}$(c), in Alberta, identified by sampling periods (cold months - blue; warm months - red).

worldwide compilation of documented data is broadening the $\delta^{18} \mathrm{O}$ range of atmospheric $\mathrm{NO}_{3}^{-}$previously suggested to be between $60 \%$ and $95 \%$ (Hastings et al., 2003; Kendall et al., 2007).

Previous studies that report triple isotope oxygen results in atmospheric $\mathrm{NO}_{3}^{-}$samples are scarce (Table 4). The $\mathrm{HNO}_{3}$ range documented here is within the broad spectrum of $p \mathrm{NO}_{3}^{-}$values compiled for remote to contaminated sites. Elliott et al. (2009) reported $\mathrm{HNO}_{3}$ oxygen results for $\delta^{18} \mathrm{O}$ values only, with a range of $+51.6 \%$ to $+94.0 \%$ (mean of 77.4), with simultaneously sampled $p \mathrm{NO}_{3}^{-} \delta^{18} \mathrm{O}$ values between $+45.2 \%$ and $+92.7 \%$ (mean of 75.2 ). Those ranges are broader than the $\mathrm{HNO}_{3}$ and $p \mathrm{NO}_{3}^{-}$values obtained in the present study.

\subsection{The $\delta^{18} \mathrm{O}$ and $\Delta^{17} \mathrm{O}$ trends in nitrates from cold and warm sampling periods}

The $\delta^{18} \mathrm{O}$ and $\Delta^{17} \mathrm{O}$ ranges for $\mathrm{HNO}_{3}$ identified by sampling period are narrower than those of the simultaneously collected $\mathrm{pNO}_{3}^{-}$(Fig. 2; Table S1), suggesting that there are additional mechanisms affecting $\mathrm{HNO}_{3}$, or that $p \mathrm{NO}_{3}$ is derived from different pathways with more variation in isotopic signatures. Overall, the $\Delta^{17} \mathrm{O}$ and $\delta^{18} \mathrm{O}$ results for $\mathrm{HNO}_{3}$, $w \mathrm{NO}_{3}^{-}$and $p \mathrm{NO}_{3}^{-}$clearly show higher $\delta^{18} \mathrm{O}$ and $\Delta^{17} \mathrm{O}$ values during cold periods relative to warm periods (Fig. 2), with the exception of $\mathrm{HNO}_{3} \delta^{18} \mathrm{O}$ values, which were similar in cold and warm periods. The collection of several samples lasted over periods overlapping fall and winter and, in such cases, the results are labelled as covering the two seasons; note that for many fall cases, the average sampling temperatures were below $0{ }^{\circ} \mathrm{C}$ (Table S3). Nevertheless, plotting by sampling period can be regarded as a general repartition of results between warm and cold months, which show lower and higher isotopic values, respectively, in both the $w$ - and $p \mathrm{NO}_{3}^{-}$.

A series of reactions listed in Table 5 summarizes the main atmospheric processes taking place during the production of nitrates in contaminated air masses. First, during anthropogenic combustion of fossil fuels, $\mathrm{NO}_{x}\left(\mathrm{NO}\right.$ and $\left.\mathrm{NO}_{2}\right)$ is produced through reactions of air $\mathrm{N}_{2}$ with atmospheric $\mathrm{O}_{2}$ at high temperatures (Reaction R1; Table 5). Then, $\mathrm{NO}_{x}$ cycles between $\mathrm{NO}$ and $\mathrm{NO}_{2}$ through a series of reactions involving sunlight (Reaction R5), $\mathrm{O}_{3}$ (Reactions R2, R4) and peroxy $\left(\mathrm{HO}_{2}\right)$ or alkyl peroxy $\left(\mathrm{RO}_{2}\right)$ radicals (Reaction R3; Morin et al., 2007; Fang et al., 2011; Michalski et al., 2014; here we use $\mathrm{RO}_{2}$ to refer collectively to $\mathrm{HO}_{2}$ and $\mathrm{RO}_{2}$ ).

The oxidation of $\mathrm{NO}_{x}$ (specifically $\mathrm{NO}_{2}$ ) to $\mathrm{HNO}_{3}$ further incorporates additional $\mathrm{O}$ atoms from different oxidants (Reactions R6-R8; Table 5). Production of nitrate via Reaction (R6) is restricted to daytime (since $\mathrm{OH}$ is generated through photochemistry), whereas production through Reactions (R4), (R7) and (R8) dominates at night. In addition, $\mathrm{N}_{2} \mathrm{O}_{5}$ is thermally unstable, so the contribution of the R4$\mathrm{R} 7-\mathrm{R} 8$ pathway is larger during winter than during summer. Additionally, in the heterogeneous hydrolysis of $\mathrm{N}_{2} \mathrm{O}_{5}$ (Reaction $\mathrm{R} 8$ ), $\mathrm{HNO}_{3}$ is likely to be retained on the reaction particle as $p \mathrm{NO}_{3}^{-}$due to its hygroscopicity (Seinfeld and Pandis, 2006). We have neglected contributions from $\mathrm{BrO}$ cycling due to the location far from the coast, and from reactions of $\mathrm{NO}_{3}$ with hydrocarbons (Reaction R12) since they are predicted to have a minimal contribution to nitrate formation in this region (Alexander et al., 2009). Finally, $\mathrm{HNO}_{3}$ in the gas phase can be irreversibly scavenged by wet surfaces or precipitation (Reaction R9) and calcium carbonate on particles (Reaction R11), and can equilibrate with solid ammonium nitrate where there is excess ammonia available (Reaction R10).

It has been previously suggested that the $\delta^{18} \mathrm{O}$ and $\Delta^{17} \mathrm{O}$ values of $w$ - and $\mathrm{pNO}_{3}^{-}$formed during summer are lower 
Table 5. Main reactions producing atmospheric nitrates (Zel'dovich, 1946; Lavoie et al., 1970; Erisman and Fowler, 2003; Michalski et al., 2003; Morino et al., 2006; Morin et al., 2007; Stroud, 2008; Michalski et al., 2014). Reactions (R1) and (R9-R12) can occur any time.

\begin{tabular}{|c|c|}
\hline Daytime - summer & Night-time - winter \\
\hline \multicolumn{2}{|c|}{$\begin{array}{l}\quad(\mathrm{R} 1) \mathrm{O}_{2}+\mathrm{Q} \rightarrow \mathrm{O}+\mathrm{O}+\mathrm{Q} ; \mathrm{N}_{2}+\mathrm{O} \rightarrow \mathrm{NO}+\mathrm{N} ; \mathrm{N}+\mathrm{O}_{2} \rightarrow \mathrm{NO}+\mathrm{O} \\
(\mathrm{R} 2) \mathrm{O}+\mathrm{O}_{2}+\mathrm{M} \rightarrow \mathrm{O}_{3} ; \mathrm{NO}+\mathrm{O}^{3} \rightarrow \mathrm{NO}_{2}+\mathrm{O}_{2} \\
(\mathrm{R} 3) \mathrm{NO}+\mathrm{RO}_{2} \rightarrow \mathrm{NO}_{2}+\mathrm{RO}\end{array}$} \\
\hline & (R4) $\mathrm{NO}_{2}+\mathrm{O}_{3} \rightarrow \mathrm{NO}_{3}+\mathrm{O}_{2}$ \\
\hline (R6) $\mathrm{NO}_{2}+\mathrm{OH}+\mathrm{M} \rightarrow \mathrm{HNO}_{3}+\mathrm{M}$ & $\begin{array}{l}\text { (R7) } \mathrm{NO}_{2}+\mathrm{NO}_{3}^{-} \leftrightarrow \mathrm{N}_{2} \mathrm{O}_{5} \\
\text { (R8) } \mathrm{N}_{2} \mathrm{O}_{5}+\mathrm{H}_{2} \mathrm{O} \text { (surface) } \rightarrow 2 \mathrm{HNO}_{3} \text { (aq)* }\end{array}$ \\
\hline \multicolumn{2}{|c|}{$\begin{array}{l}(\mathrm{R} 9) \mathrm{HNO}_{3}(\mathrm{~g}) \leftrightarrow \mathrm{HNO}_{3}(\mathrm{aq})^{*} \rightarrow \mathrm{NO}_{3}^{-}(\mathrm{aq})^{*}+\mathrm{H}^{+}(\mathrm{aq}) \\
\quad(\mathrm{R} 10) \mathrm{HNO}_{3}(\mathrm{~g})+\mathrm{NH}_{3}(\mathrm{~g}) \leftrightarrow \mathrm{NH}_{4} \mathrm{NO}_{3}(\mathrm{~s}) \\
(\mathrm{R} 11) \mathrm{HNO}_{3}(\mathrm{~g})+\mathrm{CaCO}_{3}(\mathrm{~s}) \rightarrow \mathrm{Ca}^{2}\left(\mathrm{NO}_{3}\right)_{2}(\mathrm{~s})+\mathrm{HCO}_{3} \\
\quad(\mathrm{R} 12) \mathrm{NO}_{3}+\mathrm{HC} ;\left(\mathrm{CH}_{3}\right)_{2} \mathrm{~S} \rightarrow \mathrm{HNO}_{3}+\text { products }\end{array}$} \\
\hline
\end{tabular}

$Q$ is a stable molecule of high energy; $M$ is either $\mathrm{O}_{2}$ or $\mathrm{N}_{2} ; \mathrm{RO}_{2}$ stands for both $\mathrm{HO}_{2}$ and alkyl peroxy. $\mathrm{HC}$ stands for hydrocarbons. *This aqueous nitrate may be on a particle.

than those during winter due to a higher contribution from the $\mathrm{N}_{2} \mathrm{O}_{5}$ path (Reactions $\mathrm{R} 4, \mathrm{R} 7-\mathrm{R} 8$ ) during that season (e.g., Hastings et al., 2003; Morin et al., 2008). As an early take on the data identified by sampling periods, the $w$ - and $p \mathrm{NO}_{3}^{-} \delta^{18} \mathrm{O}$ and $\Delta^{17} \mathrm{O}$ data presented here follow the same patterns for warm and cold months (Fig. 2). In contrast, the less commonly studied $\mathrm{HNO}_{3}$ shows similar $\delta^{18} \mathrm{O}$ values during warm and cold seasons, but summer $\Delta^{17} \mathrm{O}$ values mostly lower than the fall-winter, fall and spring ones.

\subsection{Correlations with meteorological parameters and co-pollutants}

The distribution and proportion of $\mathrm{HNO}_{3}$ and $p \mathrm{NO}_{3}^{-}$in polluted air masses can vary daily and seasonally with temperature, relative humidity $(\mathrm{RH})$ and concentration of cocontaminants (Morino et al., 2006). For that reason, we compared the isotopic ratios of the $\mathrm{HNO}_{3}$ and $p \mathrm{NO}_{3}$ samples $(n$ of $w \mathrm{NO}_{3}$ too low) with meteorological and air quality parameters measured routinely at nearby monitoring stations where available (Table S3). We found that the $p \mathrm{NO}_{3}^{-}$and $\mathrm{HNO}_{3} \delta^{18} \mathrm{O}$ and $\Delta^{17} \mathrm{O}$ values correlate with $\mathrm{RH}$, with $p \mathrm{NO}_{3}$ values showing stronger statistical links than $\mathrm{HNO}_{3}$ (Table 6). The $\mathrm{N}_{2} \mathrm{O}_{5}$ hydrolysis reaction (Reaction $\mathrm{R} 8$ ) rate increases with humidity (Kane et al., 2001), which may explain this positive correlation. Significant inverse relationships exist between temperature and $p \mathrm{NO}_{3}^{-} \delta^{18} \mathrm{O}, p \mathrm{NO}_{3}^{-} \Delta^{17} \mathrm{O}$ and $\mathrm{HNO}_{3} \Delta^{17} \mathrm{O}$. These negative links likely arise since $\mathrm{N}_{2} \mathrm{O}_{5}$ is more stable under cold conditions, leading to a higher contribution of $\mathrm{R} 8$. The stronger links with $p \mathrm{NO}_{3}^{-}$may be due to Reaction (R8) taking place on surfaces (such as particles) with liquid water, which is likely to retain the $\mathrm{HNO}_{3}$ as $p \mathrm{NO}_{3}^{-}$rather than release it to the gas phase. Therefore, in winter, $\mathrm{R} 8$ may contribute more to $p \mathrm{NO}_{3}^{-}$than to $\mathrm{HNO}_{3}(\mathrm{~g})$. Moreover, the highest $\delta^{18} \mathrm{O}$ and $\Delta^{17} \mathrm{O}$ values for both $p \mathrm{NO}_{3}^{-}$ and $\mathrm{HNO}_{3}$ were found for fall-winter samples collected at high RH $(76 \%)$ and low temperature $\left(-10^{\circ} \mathrm{C}\right)$. In contrast, the lowest $p \mathrm{NO}_{3}^{-}$isotopic values were found for samples with similar proportions of $\mathrm{HNO}_{3}$ and $p \mathrm{NO}_{3}^{-}$, and sampled during moderately humid $(60-63 \%)$ and warm $\left(8-20^{\circ} \mathrm{C}\right)$ periods. The accompanying shift in $\delta^{18} \mathrm{O}$ and $\Delta^{17} \mathrm{O}$ differences between $p \mathrm{NO}_{3}$ and $\mathrm{HNO}_{3}$ will help infer the mechanisms that dominate during the cold and warm periods (Sect. 4.2).

Concentrations of oxidants, co-contaminants (e.g., $\mathrm{SO}_{4}^{-}$ aerosols) and $\mathrm{NO}_{x}$ influence the dominance and rates of the discussed reactions (Brown et al., 2006; Michalski et al., 2014). However, while temperature, $\mathrm{RH}$ and $\mathrm{O}_{3}$ are well captured within a $5 \mathrm{~km}$ radius, other pollutant measurements like continuous $\mathrm{SO}_{2}, \mathrm{PM}_{2.5}$ and $\mathrm{NO}_{x}$ can have large gradients near sources; therefore it is not surprising that no correlations were found with $\mathrm{SO}_{2}$ or $\mathrm{PM}_{2.5}$ measured at sites $4-5 \mathrm{~km}$ away (Table 6). Surprisingly, only the $p \mathrm{NO}_{3}^{-} \Delta^{17} \mathrm{O}$ and $\delta^{18} \mathrm{O}$ values correlated with the fraction of each sample collected during daylight hours (i.e., between the sunrise and sunset times on the day at the middle of each sampling period, either at Edmonton or Lethbridge), which was expected for $\mathrm{HNO}_{3}$ as well due to the daytime-only $\mathrm{OH}$ pathway. However, daylight hours do not take into account light intensity, which can significantly influence the oxidation rate through this pathway and consequently both the $\delta^{18} \mathrm{O}$ and $\Delta^{17} \mathrm{O}$ values.

\subsection{Comparison with high-latitude $\mathrm{pNO}_{3}^{-}$}

An interesting aspect of the Alberta $p \mathrm{NO}_{3}^{-}$cold-period $\Delta{ }^{17} \mathrm{O}$ ranges is that they compare relatively well with the range obtained for the Canadian Arctic (Fig. 4), during winter, when night-time conditions and the $\mathrm{N}_{2} \mathrm{O}_{5}$ pathway prevail without interruption (Morin et al., 2008; for comparison with $\mathrm{HNO}_{3}$ values see Fig. S4). This observation supports the suggestion that the $\mathrm{N}_{2} \mathrm{O}_{5}$ pathway produces around $90 \%$ of nitrates during mid-latitudinal cold months (Michalski et al., 2003; Sect. 4.1). The $\delta^{18} \mathrm{O}$ ranges of cold months are similar 
Table 6. Correlation coefficients $(r)$ of $\mathrm{NO}_{3}^{-}$isotopic deltas with meteorological parameters and concentration (or ratio) of co-contaminants. In bold are the significant correlation coefficients, equal or above the $95 \%$ significance value.

\begin{tabular}{|c|c|c|c|c|c|c|c|}
\hline & $\begin{array}{l}\text { Relative } \\
\text { humidity }\end{array}$ & Temperature & $\begin{array}{l}\text { Daylight } \\
\text { (fraction) }\end{array}$ & $\mathrm{PM}$ & $\mathrm{SO}_{2}$ & $\mathrm{O}_{3}$ & \\
\hline & $\begin{array}{ll}r & R^{2}\end{array}$ & $\begin{array}{ll}r & R^{2}\end{array}$ & $\begin{array}{ll}r & R^{2}\end{array}$ & $r$ & $\mathrm{r}$ & $r$ & $R^{2}$ \\
\hline \multicolumn{8}{|l|}{$\mathrm{HNO}_{3}$} \\
\hline $\begin{array}{l}\delta^{18} \mathrm{O} \\
n \\
\Delta^{17} \mathrm{O} \\
n\end{array}$ & $\begin{array}{ll}\mathbf{0 . 8} & 0.59 \\
0.6 & \\
& 8\end{array}$ & \begin{tabular}{l}
-0.4 \\
${ }^{-0.5} 15$ \\
\multicolumn{1}{c}{15}
\end{tabular} & $\begin{array}{l}-0.3 \\
15 \\
-0.4 \\
15\end{array}$ & $\begin{array}{r}0.1 \\
13 \\
0.4 \\
13\end{array}$ & $\begin{array}{r}0.0 \\
13 \\
0.3 \\
13\end{array}$ & $\begin{array}{c}-0.29 \\
13 \\
-0.03 \\
13\end{array}$ & \\
\hline \multicolumn{8}{|l|}{$p \mathrm{NO}_{3}^{-}$} \\
\hline $\begin{array}{l}\delta^{18} \mathrm{O} \\
n \\
\Delta^{17} \mathrm{O} \\
n\end{array}$ & $\begin{array}{ll}0.9 & 0.79 \\
& 7 \\
0.9 & 0.73 \\
& 7\end{array}$ & $\begin{array}{ll}-0.6 & 0.34 \\
-0.6 & 0.34 \\
& \\
& \end{array}$ & $\begin{array}{c}-0.6 \quad 0.35 \\
-0.7 \quad 0.4 \\
15\end{array}$ & $\begin{array}{r}0.1 \\
12 \\
0.0 \\
12\end{array}$ & $\begin{array}{r}0.5 \\
12 \\
0.5 \\
12\end{array}$ & $\begin{array}{c}-\mathbf{0 . 6 1} \\
12 \\
-0.47 \\
12\end{array}$ & 0.38 \\
\hline
\end{tabular}

in Alberta and in the Arctic. This similarity goes against previous suggestions that at higher latitudes, nitrate $\delta^{18} \mathrm{O}$ annual means should be higher than at mid-latitudes due to local ambient conditions and atmospheric chemistry affecting the proportions of species involved in producing nitrate (Morin et al., 2009), namely, the sole influence of the $\mathrm{N}_{2} \mathrm{O}_{5}$ pathway during the Arctic winter (Fang et al., 2011).

The $\Delta^{17} \mathrm{O}$ departure between the Alberta and Arctic winter parallel lines is about $3 \%$. Such a difference is slightly larger than the one calculated for winter $\mathrm{NO}_{3}^{-}$at 80 and $40^{\circ} \mathrm{N}$ latitudes (about 2\%o; Morin et al., 2008). In contrast, the warm months and summer data sets for Alberta and the Arctic, respectively, show different isotopic ranges (Fig. 5), possibly due to the plume effects described later (Sect. 4.3). Moreover, contrary to a previous suggestion, the winter-summer difference in nitrate $\Delta^{17} \mathrm{O}$ values is similar at the mid- and high-latitudinal sites (about 6\%o here, and $5 \%$ in Morin et al., 2008). This similarity is likely coincidental as it may reflect the fact that within-plume chemistry may lower the $\Delta^{17} \mathrm{O}$ values of $\mathrm{NO}_{x}$ in the sampled anthropogenic plumes in Alberta (see Sect. 4.3 for details), whereas the seasonal departure in Arctic samples comes from the oxidation to nitrate through the dominant $\mathrm{OH}$ and $\mathrm{N}_{2} \mathrm{O}_{5}$ pathways during summer and winter, respectively. Finally, the $\Delta^{17} \mathrm{O}$ averages for the Alberta summer and winter results approximately fit within ranges predicted for the studied area by global modelling (Alexander et al., 2009), suggesting that global modelling of nitrate distribution worldwide is promising.

\subsection{Isotopic differences between $\mathrm{HNO}_{3}$ and $\mathrm{pNO}_{3}^{-}$}

As far as the isotopic characteristics are concerned, an important feature to keep in mind is that the $\mathrm{HNO}_{3}$ of central and southern Alberta has distinct properties relative to simulta- neously sampled $p \mathrm{NO}_{3}^{-}$. In practical terms, the relationships between the simultaneously sampled $\mathrm{HNO}_{3}$ and $p \mathrm{NO}_{3}^{-}$are of four types (Fig. 3): (i) $\mathrm{HNO}_{3} \delta^{18} \mathrm{O}$ and $\Delta^{17} \mathrm{O}$ are both lower than $p \mathrm{NO}_{3}^{-}$; (ii) $\mathrm{HNO}_{3}$ has lower $\Delta^{17} \mathrm{O}$ but higher $\delta^{18} \mathrm{O}$ values than $p \mathrm{NO}_{3}^{-}$; (iii) $\mathrm{HNO}_{3}$ has higher $\delta^{18} \mathrm{O}$ values and similar $\Delta^{17} \mathrm{O}$ ones relative to $p \mathrm{NO}_{3}^{-}$; and (iv) $\mathrm{HNO}_{3}$ has higher $\delta^{18} \mathrm{O}$ and $\Delta^{17} \mathrm{O}$ values than $\mathrm{pNO}_{3}^{-}$(Fig. 3).

The fall-winter isotopic results belong to group (i), fall results to groups (i), (ii) and (iii), and the spring and summer results to groups (ii), (iii) and (iv) (Fig. 3). Elliott et al. (2009) reported simultaneously sampled $p \mathrm{NO}_{3}^{-}$and $\mathrm{HNO}_{3}$ in the northeastern United States with similar seasonal changes of $\delta^{18} \mathrm{O}$ differences (no $\Delta^{17} \mathrm{O}$ measurement). The $\mathrm{HNO}_{3} \delta^{18} \mathrm{O}$ values were generally similar or lower than the $p \mathrm{NO}_{3}^{-}$values during winter and fall, and slightly to much higher during spring and summer, with the spring and fall $p \mathrm{NO}_{3}^{-}-\mathrm{HNO}_{3}$ relationships being roughly intermediate between the winter and summer ones. The average $\delta^{18} \mathrm{O}$ difference of $p \mathrm{NO}_{3}^{-}$minus $\mathrm{HNO}_{3}$ reported between winter and summer $(15 \%)$ by Elliott et al. (2009) agrees with the difference for fall-winter and summer obtained here $(12 \%)$.

The marked shifts in isotopic differences between the separately analyzed $\mathrm{HNO}_{3}$ and $p \mathrm{NO}_{3}^{-}$reported here likely reflect changes in the dominant reactions and processes leading to the production of the two nitrates (see Sect. 4.2). Analyzing them separately provides additional granularity that may be used to elucidate further details of the production and loss of nitrate species downwind from a $\mathrm{NO}_{x}$ source. 


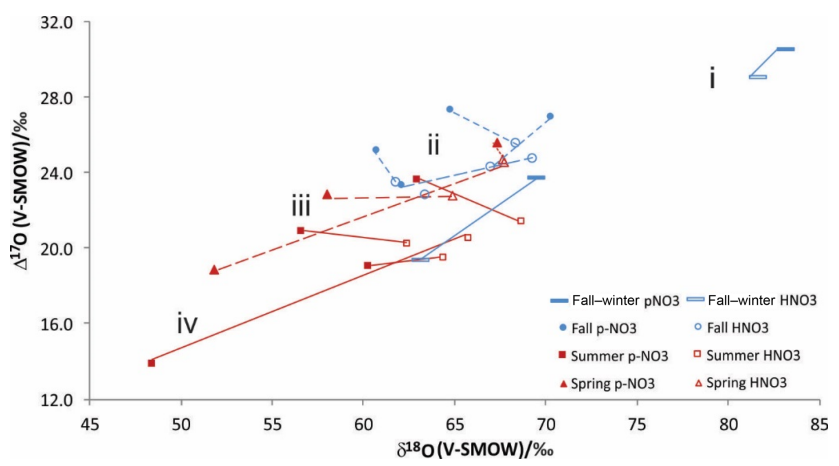

Figure 3. Line-connected $\delta^{18} \mathrm{O}$ and $\Delta^{17} \mathrm{O}$ values for simultaneously collected $\mathrm{HNO}_{3}$ (empty symbols) and $\mathrm{pNO}_{3}^{-}$(solid symbols) from cold (blue) and warm (red) sampling periods.

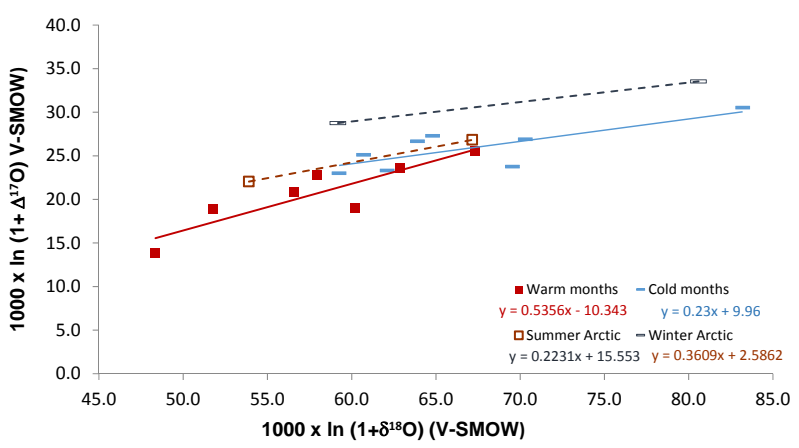

Figure 4. Isotopic results for $\mathrm{pNO}_{3}^{-}$identified by sampling periods (solid lines), compared with summer and winter trends obtained for Arctic sites (dashed lines; derived from $\ln (1+\delta)$ in Morin et al., 2008).

\section{Discussion}

\subsection{Estimation of $\Delta^{17} \mathrm{O}$ values of $\mathrm{NO}_{x}$ precursor to the studied nitrates - highlighting oxidation mechanisms}

In the present subsection, we estimate the $\Delta^{17} \mathrm{O}$ values of $\mathrm{NO}_{2}$ involved during the production of the Alberta nitrates based on the observed nitrate values and discuss the implications of these estimations. Generally, winter to summer isotopic differences are thought to be due to the high oxygen isotopic values of $\mathrm{N}_{2} \mathrm{O}_{5}$ due to interaction with $\mathrm{O}_{3}$ (Johnston and Thiemens, 1997; Michalski et al., 2003; Morin et al., 2008; Vicars et al., 2012) and low values of $\mathrm{OH}$ in isotopic equilibrium with atmospheric $\mathrm{H}_{2} \mathrm{O}$ (Dubey et al., 1997). According to Table 5, the first reaction pathway produces nitrates via R4-R7-R8 with two-thirds of the $\mathrm{O}$ atoms coming from $\mathrm{NO}_{2}$, one-sixth from $\mathrm{O}_{3}$ and one-sixth from $\mathrm{H}_{2} \mathrm{O}$, while the second produces nitrates via Reaction (R6) with two out of three $\mathrm{O}$ atoms coming from $\mathrm{NO}_{2}$ and one-third from $\mathrm{OH}$ (e.g., Michalski et al., 2003). Using these proportions with the Alberta $\Delta^{17} \mathrm{O}$ values of $p \mathrm{NO}_{3}^{-}$and $\mathrm{HNO}_{3}$ in weighted averages allows us to make a rough estimation of the maximum and minimum $\Delta{ }^{17} \mathrm{O}$ values of $\mathrm{NO}_{2}$ oxidized to nitrates in the air masses sampled. The calculations assume the $\mathrm{O}$ from $\mathrm{O}_{3}$ contributes a signal of $\sim 39 \%$ as was recently measured (Vicars and Savarino, 2014) and that $\Delta^{17} \mathrm{O}$ of $\mathrm{OH}$ and $\mathrm{H}_{2} \mathrm{O}$ are zero. The estimated $\mathrm{NO}_{2} \Delta^{17} \mathrm{O}$ values for fall-winter (34\%o-45\%o daytime, $25 \%$ o-36\%o nighttime) and for summer (25\%o-34\%o for daytime; $15 \%$ - $24 \%$ o for night-time) represent the extremes, assuming daytime oxidation takes place $100 \%$ through the $\mathrm{OH}$ pathway and nighttime oxidation takes place entirely through the $\mathrm{N}_{2} \mathrm{O}_{5}$ pathway. One should keep in mind that the Alberta results are for nitrates collected during multi-week sampling periods. Each nitrate sample therefore contains a mixture of $\mathrm{O}$ from the pathways operating during daytime (Reaction R6) and nighttime (Reactions R4-R7-R8) a priori. Assuming a 50\% contribution from each pathway for summer, we generate values ranging from $20 \%$ to $29 \%$ o. Alternatively, assuming domination of the $\mathrm{N}_{2} \mathrm{O}_{5}$ pathway during winter $(90 \%$; Michalski et al., 2014), the range is $26 \%$ o- $37 \%$ o. Fall and spring values should fit between these summer and winter estimated ranges. The estimated $\mathrm{NO}_{2} \Delta{ }^{17} \mathrm{O}$ ranges indicate that the potential parent $\mathrm{NO}_{2}$ had a smaller ${ }^{17} \mathrm{O}$ anomaly than $\mathrm{O}_{3}$ (39\%o; Vicars and Savarino, 2014) or $\mathrm{NO}_{2}$ in isotopic equilibrium with $\mathrm{O}_{3}$ alone (45\%; Michalski et al., 2014) in all possible scenarios.

Two mechanisms could be responsible for the $\Delta^{17} \mathrm{O}$ differences between these estimates and $\mathrm{NO}_{2}$ in isotopic equilibrium with $\mathrm{O}_{3}$. One is the competition of Reaction (R3) with Reaction (R2) in oxidizing $\mathrm{NO}$ to $\mathrm{NO}_{2}$, since $\mathrm{RO}_{2}$ will decrease the $\Delta^{17} \mathrm{O}$ values relative to an ozone-only equilibrium. The relative reaction rates of Reactions (R2) and (R3) have previously been presumed to control the $\mathrm{NO}_{2}$ isotopic composition (e.g., Alexander et al., 2009) based on the assumption of isotopic steady state. A larger contribution of $\mathrm{RO}_{2}$ is expected in the $\mathrm{NO}_{2}$ precursors for summer relative to winter, since biogenic VOCs that are major sources of $\mathrm{RO}_{2}$ radicals are much higher in the summer (e.g., Fuentes and Wang, 1999). This suggestion is consistent with the lower $\Delta{ }^{17} \mathrm{O}$ ranges in summer reported here. A second possibility is that the nitrates were formed from some $\mathrm{NO}_{x}$ that did not reach an isotopic steady state with $\mathrm{O}_{3}$, retaining some of its original signature (assumed to be $\Delta^{17} \mathrm{O}=0 \%$ ). Most studies have assumed that an isotopic steady state is established between $\mathrm{O}_{3}$ and $\mathrm{NO}_{2}$ within a few minutes after emission of $\mathrm{NO}_{x}$ from a combustion source - or at least, that nitrate formation is negligible before $\mathrm{NO}_{x}$ isotopic equilibrium is reached. However, recent modelling by Michalski et al. (2014) suggests that isotopic equilibration of $\mathrm{NO}_{x}$ with $\mathrm{O}_{3}$ could take from several minutes up to a few hours at the relatively low $\mathrm{O}_{3}$ concentrations in rural Alberta. At the measured average wind speeds on site of $8-19 \mathrm{~km} \mathrm{~h}^{-1}$, transit times from the nearest sources to observation sites are estimated to be $9-55 \mathrm{~min}$. While the fraction of $\mathrm{NO}_{x}$ converted to nitrate in this transit time may be small, these are large 


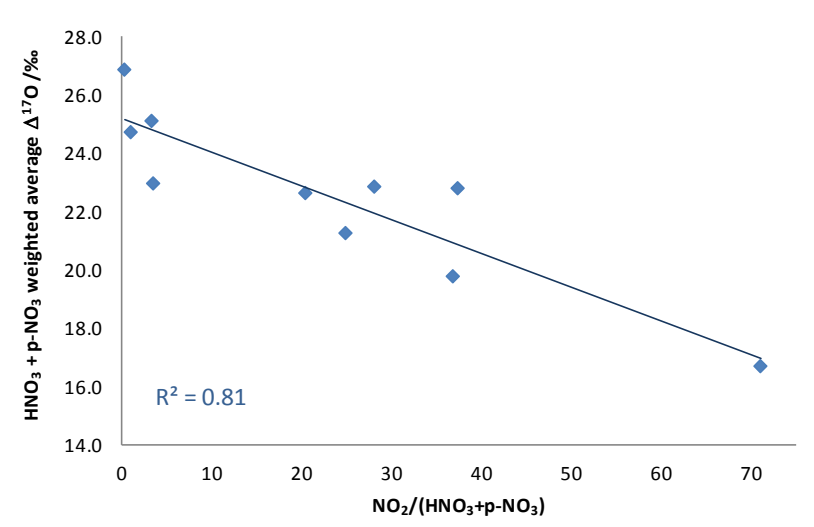

Figure 5. Weighted $\Delta^{17} \mathrm{O}$ average for the sum of dry nitrates as a function of $\mathrm{NO}_{2}$ concentration divided by $p \mathrm{NO}_{3}$ plus $\mathrm{HNO}_{3}$ concentrations, a ratio indicative of the maturity of a plume.

sources of $\mathrm{NO}_{x}$ in an area with very low background nitrates. For example, a plume containing $10 \mathrm{nmol} \mathrm{mol}^{-1}$ of $\mathrm{NO}_{2}$ mixing with background air with $0.1 \mathrm{pmol} \mathrm{mol}^{-1}$ of $\mathrm{OH}$ (Howell et al., 2014) would produce $\mathrm{HNO}_{3}$ via Reaction (R6) at a rate of $0.011 \mu \mathrm{g} \mathrm{m}^{-3} \mathrm{~min}^{-1}$ of $\mathrm{NO}_{3}^{-}-\mathrm{N}$ at $T=7{ }^{\circ} \mathrm{C}$ (Burkholder et al., 2015), or an equivalent amount of a typical nitrate sample in $10 \mathrm{~min}$ (Table S1). Even if equilibration with $\mathrm{O}_{3}$ is established within a few minutes, the nitrate produced in the interim can constitute a substantial fraction of the sample collected nearby. Therefore, the nitrates measured at our sites may partly derive from $\mathrm{NO}_{x}$ that had not yet reached an isotopic steady state with $\mathrm{O}_{3}$. These two mechanisms are not exclusive and could both contribute to lower $\mathrm{NO}_{x}$, and therefore nitrate, $\Delta^{17} \mathrm{O}$ values.

An additional piece of evidence suggests that the $\mathrm{NO}_{x}$ plumes themselves, rather than ambient conditions, are the source of low- $\Delta^{17} \mathrm{O}$ nitrates in these samples. There is a strong correlation between the total nitrate $\Delta^{17} \mathrm{O}$ values and the maturity of the plume as expressed by the $\mathrm{NO}_{2}$ concentration divided by the sum of $\mathrm{HNO}_{3}$ and $p \mathrm{NO}_{3}^{-}$concentrations (Fig. 5). This observation is consistent with the unequilibrated $\mathrm{NO}_{2}$ hypothesis. However, it does not rule out the possible contribution of $\mathrm{RO}_{2}$, since VOC releases from the $\mathrm{NO}_{x}$ sources could lead to elevated $\mathrm{RO}_{2}$ concentrations in the plume.

\subsection{Causes of shifts in $\mathrm{HNO}_{3}$ to $\mathrm{pNO}_{3}^{-}$isotopic differences}

A challenging question is as follows: why do the $\mathrm{HNO}_{3}$ to $p \mathrm{NO}_{3}^{-}$isotopic differences shift seasonally (Fig. 3)? One factor that may influence the relationship between $\mathrm{HNO}_{3}$ and $p \mathrm{NO}_{3}^{-}$is the mass-dependent isotopic equilibrium between $\mathrm{NH}_{4} \mathrm{NO}_{3}$ and $\mathrm{HNO}_{3}$ (Reaction R10); however, this mechanism would result in higher $\delta^{18} \mathrm{O}$ in $p \mathrm{NO}_{3}^{-}$and unchanged $\Delta^{17} \mathrm{O}$ values and, therefore, cannot be solely responsible for any of the observed patterns (Fig. 3). Alternately, the trend for cold months (trend i) could be due to the fact that the heterogeneous $\mathrm{N}_{2} \mathrm{O}_{5}$ pathway is likely to produce more $p \mathrm{NO}_{3}^{-}$ than $\mathrm{HNO}_{3}(\mathrm{~g})$, which would result in a higher contribution from ozone and explain why $\delta^{18} \mathrm{O}$ and $\Delta^{17} \mathrm{O}$ values are both higher in $p \mathrm{NO}_{3}^{-}$. A previous study addressing why $p \mathrm{NO}_{3}^{-}$ on coarse particles is more enriched than on fine particles invoked a similar explanation (Patris et al., 2007).

For some of the spring and summer samples, both $\delta^{18} \mathrm{O}$ and $\Delta^{17} \mathrm{O}$ values were lower in $p \mathrm{NO}_{3}^{-}$than in $\mathrm{HNO}_{3}$ (trend iv). Therefore the mechanism above cannot dominate the fractionation; nor can a mass-dependent process be responsible. We suggest a different fractionation process because $\mathrm{HNO}_{3}$ dry-deposits to surfaces more rapidly than $p \mathrm{NO}_{3}^{-}$ (Zhang et al., 2009; Benedict et al., 2013), which would create the discussed isotopic shifts in the situation where $\mathrm{NO}_{2}$ has low $\Delta^{17} \mathrm{O}$ values in a fresh plume. The first nitrates formed in the plume shortly after emission from the $\mathrm{NO}_{x}$ source have low $\delta^{18} \mathrm{O}$ and $\Delta^{17} \mathrm{O}$ values, either because $\mathrm{NO}_{x}$ has not yet reached an isotopic steady state with $\mathrm{O}_{3}$ or because it reacted with ${ }^{17} \mathrm{O}$-poor $\mathrm{RO}_{2}$ present in the plume due to VOC emissions. Those nitrates that form as $\mathrm{pNO}_{3}^{-}$ or that partition to $p \mathrm{NO}_{3}^{-}$remain in the plume for longer than $\mathrm{HNO}_{3}$, which is removed from the plume rapidly upon contact with vegetation or other surfaces. As the plume travels, the $\mathrm{NO}_{x}$ becomes more enriched, and the newly formed nitrates take on higher $\delta^{18} \mathrm{O}$ and $\Delta^{17} \mathrm{O}$ values. However, $p \mathrm{NO}_{3}^{-}$collected further downwind will derive from a mixture of low- $\delta^{18} \mathrm{O}$ and $-\Delta^{17} \mathrm{O} p \mathrm{NO}_{3}^{-}$formed earlier, plus high$\delta^{18} \mathrm{O}$ and $-\Delta^{17} \mathrm{O} p \mathrm{NO}_{3}^{-}$formed more recently, while $\mathrm{HNO}_{3}$ will have a larger proportion formed more recently and will therefore have higher $\delta^{18} \mathrm{O}$ and $\Delta^{17} \mathrm{O}$ values. The fact that we find the lowest isotopic values in summer $p \mathrm{NO}_{3}^{-}$samples collected from various anthropogenic sources at distances less than $16 \mathrm{~km}$ supports this suggestion (Table 1).

The above two mechanisms that we propose to explain the shifts in $\mathrm{HNO}_{3}$ to $p \mathrm{NO}_{3}$ isotopic differences between cold and warm sampling periods - a differential $\mathrm{N}_{2} \mathrm{O}_{5}$ contribution resulting in higher $\Delta^{17} \mathrm{O}$ values in $p \mathrm{NO}_{3}^{-}$than in $\mathrm{HNO}_{3}$, and a differential deposition resulting in lower $\Delta^{17} \mathrm{O}$ values in $p \mathrm{NO}_{3}$ - would essentially compete against each other, with local conditions and chemistry influencing the results. In winter, when the $\mathrm{N}_{2} \mathrm{O}_{5}$ pathway is most important, the first mechanism dominates, as supported by the observation that $p \mathrm{NO}_{3}^{-}$concentrations are higher during that season (trend i). Conversely, in summer, when the $\mathrm{N}_{2} \mathrm{O}_{5}$ pathway is less important and dry deposition is likely faster due to absence of snow cover, higher surface wetness and high leaf areas, the second mechanism is more important (trend iv). The local reactant concentrations, wind speeds and radiative fluxes (which control the time to reach an isotopic equilibrium) would also be factors in the second mechanism. We find intermediate trends (ii, iii) in the transitional seasons, as expected. In addition to these non-mass-dependent fractionation processes, mass-dependent fractionation in formation and loss of nitrate likely contributes to the observed $\delta^{18} \mathrm{O}$ dif- 


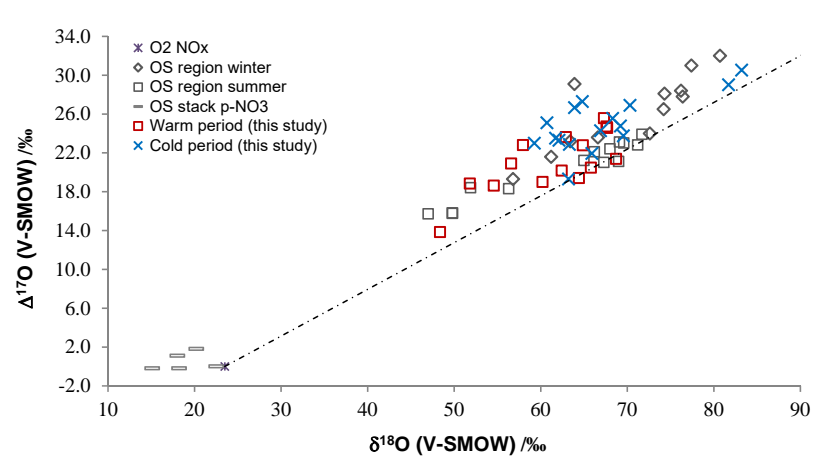

Figure 6. Isotopic ratios for atmospheric $p \mathrm{NO}_{3}^{-}, w \mathrm{NO}_{3}^{-}$and $\mathrm{HNO}_{3}$ samples in cold and warm periods from central and southern Alberta (this study), compared with previously published winter and summer bulk and throughfall deposition samples from the oil sands (OS) region from northern Alberta (Proemse et al., 2013), and $\mathrm{pNO}_{3}^{-}$instack emissions data for an OS upgrader located in the same region (Proemse et al., 2012). The grey dotted line connects $\mathrm{NO}_{x}$ from theoretical combustion with $\mathrm{O}_{2}$ isotopic composition and at isotopic equilibrium with tropospheric $\mathrm{O}_{3}$ (Michalski et al., 2014).

ferences. For instance, kinetic fractionation may be involved in the production of trend iii.

In summary, examining the isotopic relationship of $\mathrm{HNO}_{3}$ to $p \mathrm{NO}_{3}^{-}$(Fig. 3) reveals the complexity of anthropogenic $\mathrm{NO}_{x}$ oxidation mechanisms. The lower $p \mathrm{NO}_{3}^{-}$isotopic values relative to the $\mathrm{HNO}_{3}$ values during warm months may reflect differential removal rates from plumes containing $\mathrm{NO}_{2}$ temporarily low in ${ }^{17} \mathrm{O}$.

\subsection{Low $\delta^{18} \mathrm{O}$ and $\Delta^{17} \mathrm{O}$ trends in global $w$ - and $p \mathrm{NO}_{3}^{-}$ - implications for polluted air masses}

Atmospheric nitrates measured in central and southern Alberta were sampled downwind of well-identified anthropogenic sources to verify the potential role of emitted $\mathrm{NO}_{x}$ isotopic signals through to final nitrate isotopic ratios (primarily N isotopes; see Savard et al., 2017). As expected, the measured oxygen isotopes of the various nitrate groups are consistent with exchange with $\mathrm{O}_{3}$ and oxidation through the well-known $\mathrm{OH}$ and $\mathrm{N}_{2} \mathrm{O}_{5}$ oxidation paths. However, $\mathrm{NO}_{2}$ not in isotopic equilibrium with $\mathrm{O}_{3}$, and/or $\mathrm{NO}$ reacted with $\mathrm{RO}_{2}$, may have significantly influenced the overall results. Co-contaminants in the emissions and sampling plumes at short distances from the sources may have favoured these two mechanisms, and quantifying $\mathrm{RO}_{2}$ and/or $\mathrm{HO}_{2}$ would help distinguish between the two mechanisms. Meanwhile, our results raise the following question: are these overall effects observable in triple oxygen isotopes of nitrates from other polluted sites?

The full $\Delta^{17} \mathrm{O}$ and $\delta^{18} \mathrm{O}$ ranges for $p \mathrm{NO}_{3}^{-}, w \mathrm{NO}_{3}^{-}$and $\mathrm{HNO}_{3}$ (between $13.8 \%$ and $20.5 \%$ and $48.4 \%$ and $83.2 \%$; Table 4) compare well with the isotopic ranges obtained for bulk deposition $\mathrm{NO}_{3}^{-}$samples collected downwind from oil sands mining operations in the lower Athabasca region farther north in Alberta (Proemse et al., 2013). Moreover, the isotopic values in cold and warm months delineated here essentially overlap with the data sets of winter and summer from the lower Athabasca region (Fig. 6). This correspondence exists despite the slightly different climatic conditions (Fig. S1) and very different sampling methods (bulk/throughfall deposition samples using open ion exchange resin collectors vs. wind-sector-specific active sampling on filters and precipitation-only collectors). Notably, many points carry relatively low $\delta^{18} \mathrm{O}$ and $\Delta^{17} \mathrm{O}$ values.

Previous work in the Athabasca region reported very low $\delta^{18} \mathrm{O}$ and near-zero $\Delta^{17} \mathrm{O}$ values for $p \mathrm{NO}_{3}^{-}$sampled directly within oil sands industrial stacks, i.e., in the emissions measured in-stack and diluted with ambient air (Proemse et al., 2012). These values are very close to those of $\mathrm{O}_{2}$. Similar isotopic signatures are very likely produced in source emissions of $\mathrm{NO}_{x}$ in the studied Edmonton and Vauxhall areas (e.g., CFPPs, gas compressors, industries). This source signature may persist into $p \mathrm{NO}_{3}$ collected close to the sources. Within the first few hours in the atmosphere (less, in polluted areas), the $\mathrm{NO}_{x} \delta^{18} \mathrm{O}$ and $\Delta^{17} \mathrm{O}$ values rapidly increase due to isotope exchange with $\mathrm{O}_{3}$ (Reactions $\mathrm{R} 2, \mathrm{R} 3, \mathrm{R} 5$ and $\mathrm{O}_{3}$ formation, Table 5; Michalski et al., 2014) and reach isotopic equilibrium. Though the e-folding lifetime for $\mathrm{NO}_{x}$ oxidation to nitrates may be longer than these few hours, depending on the $\mathrm{NO}_{x} / \mathrm{VOC}$ ratio, only a fraction of the oxidized source $\mathrm{NO}_{x}$ will create a measurable contribution to the ambient nitrate where the background air is very low in nitrate. This is likely the case in the oil sands region, where Proemse et al. (2013) reported the lowest $\Delta^{17} \mathrm{O}$ values within $12 \mathrm{~km}$ of the emission sites, and where direct stack emissions of $p \mathrm{NO}_{3}^{-}$were $\sim 5000$ times lower than $\mathrm{NO}_{x}$ emissions (Wang et al., 2012).

In a methodological test study, we obtained low values for $w \mathrm{NO}_{3}^{-}$sampled near a high traffic volume highway in Ontario, Canada (Smirnoff et al., 2012). Low $\delta^{18} \mathrm{O}$ and $\Delta^{17} \mathrm{O}$ values in atmospheric nitrates during warm months (65 and $20 \%$ or less, respectively) have been reported for other parts of the world as well (Table 4). Authors of these studies have invoked peroxy radicals to account for low $\delta^{18} \mathrm{O}$ values in $w \mathrm{NO}_{3}^{-}$from a polluted city (Fang et al., 2011), in $p \mathrm{NO}_{3}^{-}$ from Taiwan collected partly from air masses influenced by pollutants (Guha et al., 2017) and from a polluted coastal site in California (Michalski et al., 2004; Patris et al., 2007; Table 4). However, sampling in these three other regions did not use collection restricted to air masses transported from targeted anthropogenic sources. So uncertainties persist regarding the ultimate sources of nitrates with low isotopic values.

Although a few low values are also reported for seemingly non-polluted areas of the Arctic and Antarctic regions (unknown cause; Morin et al., 2008, 2009) and of coastal California (Patris et al., 2007), the information from the literature integrated with the interpretation proposed for the Alberta low $\delta^{18} \mathrm{O}$ and $\Delta^{17} \mathrm{O}$ values in summer nitrates may reflect 
the involvement of air masses that include nitrates from oxidation of $\mathrm{NO}_{2}$ with light isotopes in plumes. In such cases, while not ruling out a higher contribution from $\mathrm{RO}_{2}$ oxidation of $\mathrm{NO}$, it is also possible that significant portions of the collected nitrate were formed before the $\mathrm{NO}_{x}-\mathrm{O}_{3}$ isotopic equilibrium was reached (see Sect. 4.1). Keeping in mind that other hydrocarbon and halogen pathways may play a role in determining the isotopic nitrate characteristics in other parts of the world, we propose that, in general, the warm periods' isotopic ranges appear to be lower in polluted areas. Given these points, our nitrate $\delta^{18} \mathrm{O}$ and $\Delta^{17} \mathrm{O}$ may reflect relative proximity to anthropogenic $\mathrm{N}$ emitters in general. Further research work on plume $\mathrm{NO}_{x}$ to nitrates chemical mechanisms may help to validate this suggestion. In the future, the assumption of an $\mathrm{NO}_{x}$ isotopic steady state with $\mathrm{O}_{3}$ should be explored, given recent findings (Michalski et al., 2014), the critical importance of $\mathrm{NO}_{x}$ isotope characteristics on resulting nitrate isotopic values (Alexander et al., 2009) and the suggestion regarding the evolution of $\mathrm{NO}_{x}-\mathrm{NO}_{3}^{-}$signals in fresh anthropogenic plumes (present study).

\section{Conclusion}

The $\mathrm{HNO}_{3}, w \mathrm{NO}_{3}$ and $p \mathrm{NO}_{3}$ from anthropogenic sources in central and southern Alberta, simultaneously collected with wind-sector-based conditional sampling systems, produced $\delta^{18} \mathrm{O}$ and $\Delta^{17} \mathrm{O}$ trends confirming the previous contention that regional ambient conditions (e.g., light intensity, oxidant concentrations, $\mathrm{RH}$, temperature) dictate the triple isotopic characteristics and oxidation pathways of nitrates.

The gaseous form of nitrate $\left(\mathrm{HNO}_{3}\right)$, having distinct isotopic characteristics relative to the wet and particulate forms, implies that understanding nitrate formation and loss requires the nitrate species to be characterized individually. Particulate $\mathrm{NO}_{3}^{-}$in these samples generally shows higher $\delta^{18} \mathrm{O}$ and $\Delta^{17} \mathrm{O}$ values than $\mathrm{HNO}_{3}$ in the fall-winter period as the heterogeneous $\mathrm{N}_{2} \mathrm{O}_{5}$ pathway favours the production of $p \mathrm{NO}_{3}^{-}$. In contrast, $\mathrm{HNO}_{3}$ has higher $\delta^{18} \mathrm{O}$ and $\Delta^{17} \mathrm{O}$ values during warm periods, which we propose is due to faster dry deposition rates relative to $p \mathrm{NO}_{3}^{-}$in the event that low- $\Delta{ }^{17} \mathrm{O} \mathrm{NO}_{2}$ is oxidized in the plume. The mechanisms conferring nitrate with relatively low isotopic values, whether oxidation before the $\mathrm{NO}_{x}-\mathrm{O}_{3}$ equilibrium is reached or higher contributions from $\mathrm{RO}_{2}$, are likely to be observed in anthropogenic polluted air masses. An interesting deduction arising from this interpretation and from a comparison with nitrate isotopes from other polluted areas of the world is that relatively low $\delta^{18} \mathrm{O}$ and $\Delta^{17} \mathrm{O}$ values may reflect nitrates produced from undifferentiated anthropogenic $\mathrm{NO}_{x}$ emissions.

Future research should explore the assumption of $\mathrm{NO}_{x}$ isotopic equilibration with $\mathrm{O}_{3}$, given the critical importance of $\mathrm{NO}_{x}$ isotopes on resulting nitrate isotopic values. More field sampling, including additional on-site oxidant data, and state-of-the-art isotopic analyses of all tropospheric nitrate species as well as $\mathrm{NO}_{x}$ are required for refining our under- standing of atmospheric nitrate worldwide. This endeavour is fundamental for developing effective emission reduction strategies towards improving future air quality.

Data availability. All data interpreted and discussed in the article are presented in the Supplement (Tables S1, S2 and S3).

Supplement. The supplement related to this article is available online at: https://doi.org/10.5194/acp-18-10373-2018-supplement.

Author contributions. MMS contributed scientific leadership and expertise in isotope geochemistry, integrated and interpreted all data, and wrote most of the article. ASC contributed expertise in atmospheric chemistry and isotope geochemistry, participated in all aspects of the interpretation, and greatly helped in the writing of the article. RV was responsible for designing and supervising the air sampling missions. AS was responsible for conducting the air sample preparation and their isotopic analyses and insuring the QA and QC of the produced results.

Competing interests. The authors declare that they have no conflict of interest.

Acknowledgements. The authors are grateful for the technical support provided by Marie-Christine Simard and Jade Bergeron of the Geological Survey of Canada and by Syed Iqbal, Rachel Mintz, Daniel McLennan, Matthew Parsons, Mike Shaw and Amy Hou of Environment and Climate Change Canada, and for the constructive pre-submission review by Geneviève Bordeleau from the Geological Survey of Canada and Felix Vogel and Jason O'Brien from ECCC. This research has been financially supported by the Clean Air Regulatory Agenda of Environment and Climate Change Canada and the Environmental Geoscience program of Natural Resources Canada (NRCan contribution number: 20170310). The first author dedicates this research article to Pauline Durand for her support.

Edited by: Jan Kaiser

Reviewed by: three anonymous referees

\section{References}

Alexander, B., Hastings, M. G., Allman, D. J., Dachs, J., Thornton, J. A., and Kunasek, S. A.: Quantifying atmospheric nitrate formation pathways based on a global model of the oxygen isotopic composition $\left(\Delta^{17} \mathrm{O}\right)$ of atmospheric nitrate, Atmos. Chem. Phys., 9, 5043-5056, https://doi.org/10.5194/acp-9-5043-2009, 2009.

Anlauf, K. G., Fellin, P., Wiebe, H. A., Schiff, H. I., Mackay, G. I., Braman, R. S., and Gilbert, R.: A comparison of three methods for measurement of atmospheric nitric acid and 
aerosol nitrate and ammonium, Atmos. Environ., 19, 325-333, https://doi.org/10.1016/0004-6981(85)90100-3, 1985.

Anlauf, K. G., Wiebe, H. A., and Fellin, P.: Characterization of Several Integrative Sampling Methods for Nitric Acid, Sulphur Dioxide and Atmospheric Particles, JAPCA J. Air Waste Ma., 36, 715-723, https://doi.org/10.1080/00022470.1986.10466107, 1986.

Appel, B. R., Tokiwa, Y., and Haik, M.: Sampling of nitrates in ambient air, Atmos. Environ., 15, 283-289, https://doi.org/10.1016/0004-6981(81)90029-9, 1981.

Benedict, K. B., Carrico, C. M., Kreidenweis, S. M., Schichtel, B., Malm, W. C., and Collett Jr., J. L.: A seasonal nitrogen deposition budget for Rocky Mountain National Park, Ecol. Appl., 23, 1156-1169, https://doi.org/10.1890/12-1624.1, 2013.

Brown, S. S., Ryerson, T. B., Wollny, A. G., Brock, C. A., Peltier, R., Sullivan, A. P., Weber, R. J., Dubé, W. P., Trainer, M., Meagher, J. F., Fehsenfeld, F. C., and Ravishankara, A. R.: Variability in nocturnal nitrogen oxide processing and its role in regional air quality, Science, 311, 67-70, https://doi.org/10.1126/science.1120120, 2006.

Burkholder, J. B., Sander, S. P., Abbatt, J., Barker, J. R., Huie, R. E., Kolb, C. E., Kurylo, M. J., Orkin, V. L., Wilmouth, D. M., and Wine, P. H.: Chemical Kinetics and Photochemical Data for Use in Atmospheric Studies, Evaluation No. 18, Jet Propulsion Laboratory, Pasadena, CA, USA, JPL Publication 15-10, 2015.

Cheng, I. and Zhang, L.: Long-term air concentrations, wet deposition, and scavenging ratios of inorganic ions, $\mathrm{HNO}_{3}$, and $\mathrm{SO}_{2}$ and assessment of aerosol and precipitation acidity at Canadian rural locations, Atmos. Chem. Phys., 17, 4711-4730, https://doi.org/10.5194/acp-17-4711-2017, 2017.

Coplen, T. B., Böhlke, J. K., and Casciotti, K.: Using dual-bacterial denitrification to improve $\mathrm{d}^{15} \mathrm{~N}$ determinations of nitrates containing mass-independent ${ }^{17} \mathrm{O}$, Rapid Commun. Mass Sp., 18, 245-250, 2004.

Dahal, B. and Hastings, M. G.: Technical considerations for the use of passive samplers to quantify the isotopic composition of $\mathrm{NO}_{x}$ and $\mathrm{NO}_{2}$ using the denitrifier method, Atmos. Environ., 143, 6066, 2016.

Dubey, M. K., Mohrschladt, R., Donahue, N. M., and Anderson, J. G.: Isotope specific kinetics of hydroxyl radical $(\mathrm{OH})$ with water $\left(\mathrm{H}_{2} \mathrm{O}\right)$ : Testing models of reactivity and atmospheric fractionation, J. Phys. Chem. A, 101, 1494-1500, 1997.

Elliott, E. M., Kendall, C., Boyer, E. W., Burns, D. A., Lear, G. G., Golden, H. E., Harlin, K., Bytnerowicz, A., Butler, T. J., and Glatz, R.: Dual nitrate isotopes in dry deposition: Utility for partitioning $\mathrm{NO}_{x}$ source contributions to landscape nitrogen deposition, J. Geophys. Res.-Biogeo., 114, G04020, https://doi.org/10.1029/2008JG000889, 2009.

Environment and Climate Change Canada: Air Pollutant Emission Inventory Online Data Query, available at: http://www. ec.gc.ca/inrp-npri/donnees-data/ap/index.cfm?lang=En, last access: 15 December 2016.

Environment and Climate Change Canada: Canadian Air and Precipitation Monitoring Network (CAPMoN), available at: http://donnees.ec.gc.ca/data/air/monitor/ monitoring-of-atmospheric-precipitation-chemistry/ major-ions/, last access: 17 May 2018a.

Environment and Climate Change Canada: National Pollutant Release Inventory, available at: https://www. canada.ca/en/environment-climate-change/services/ national-pollutant-release-inventory/tools-resources-data.html, last access: 22 May 2018b.

Erisman, J. W. and Fowler, D.: Oxidized and reduced nitrogen in the atmosphere, Knowledge for Sustainable Development, An Insight into the Encyclopedia of Life Support Systems, Volumes I, II, III, UNESCO Publishing-Eolss Publishers, Oxford, UK, 2003.

Fang, Y. T., Koba, K., Wang, X. M., Wen, D. Z., Li, J., Takebayashi, Y., Liu, X. Y., and Yoh, M.: Anthropogenic imprints on nitrogen and oxygen isotopic composition of precipitation nitrate in a nitrogen-polluted city in southern China, Atmos. Chem. Phys., 11, 1313-1325, https://doi.org/10.5194/acp-111313-2011, 2011.

Fuentes, J. D. and Wang, D.: On the seasonality of isoprene emissions from a mixed temperate forest, Ecol. Appl., 9, 1118-1131, https://doi.org/10.1890/10510761(1999)009[1118:OTSOIE]2.0.CO;2, 1999.

Guha, T., Lin, C. T., Bhattacharya, S. K., Mahajan, A. S., OuYang, C. F., Lan, Y. P., Hsu, S. C., and Liang, M. C.: Isotopic ratios of nitrate in aerosol samples from Mt. Lulin, a highaltitude station in Central Taiwan, Atmos. Environ., 154, 53-69, https://doi.org/10.1016/j.atmosenv.2017.01.036, 2017.

Hastings, M. G., Sigman, D. M., and Lipschultz, F.: Isotopic evidence for source changes of nitrate in rain at Bermuda, J. Geophys. Res.-Atmos., 108, ACH 22-21-ACH 22-12, 2003.

Howell, S. G., Clarke, A. D., Freitag, S., McNaughton, C. S., Kapustin, V., Brekovskikh, V., Jimenez, J.-L., and Cubison, M. J.: An airborne assessment of atmospheric particulate emissions from the processing of Athabasca oil sands, Atmos. Chem. Phys., 14, 5073-5087, https://doi.org/10.5194/acp-145073-2014, 2014.

IPCC: Fifth Assessment Report (AR5), available at: https://www. ipcc.ch/report/ar5/ (last access: 11 September 2017), 2013.

Johnston, J. C. and Thiemens, M. H.: The isotopic composition of tropospheric ozone in three environments, J. Geophys. Res.Atmos., 102, 25395-25404, 1997.

Kaiser, J., Hastings, M. G., Houlton, B. Z., Röckmann, T., and Sigman, D. M.: Triple oxygen isotope analysis of nitrate using the denitrifier method and thermal decomposition of $\mathrm{N}_{2} \mathrm{O}$, Anal. Chem., 79, 599-607, https://doi.org/10.1021/ac061022s, 2007.

Kane, S. M., Caloz, F., and Leu, M. T.: Heterogeneous uptake of gaseous $\mathrm{N}_{2} \mathrm{O}_{5}$ by $\left(\mathrm{NH}_{4}\right)_{2} \mathrm{SO}_{4}, \mathrm{NH}_{4} \mathrm{HSO}_{4}$, and $\mathrm{H}_{2} \mathrm{SO}_{4}$ aerosols, J. Phys. Chem. A, 105, 6465-6470, https://doi.org/10.1021/jp010490x, 2001.

Keck, L. and Wittmaack, K.: Effect of filter type and temperature on volatilisation losses from ammonium salts in aerosol matter, Atmos. Environ., 39, 4093-4100, https://doi.org/10.1016/j.atmosenv.2005.03.029, 2005.

Kendall, C., Elliott, E. M., and Wankel, S. D.: Tracing Anthropogenic Inputs of Nitrogen to Ecosystems, in: Stable Isotopes in Ecology and Environmental Science, Blackwell Publishing, Mailden, MA, USA, 2nd edn., 375-449, 2007.

Lavoie, G. A., Heywood, J. B., and Keck, J. C.: Experimental And Theoretical Study Of Nitric Oxide Formation In Internal Combustion Engines, M.I.T.-Dept. Mech. Eng.-Fluid Mechanics Laboratory Publ., 69-10, 1969. 
Liang, M. C. and Yung, Y. L.: Sources of the oxygen isotopic anomaly in atmospheric $\mathrm{N}_{2} \mathrm{O}$, J. Geophys. Res.-Atmos., 112, D13307, https://doi.org/10.1029/2006JD007876, 2007.

McIlvin, M. R. and Altabet, M. A.: Chemical conversion of nitrate and nitrite to nitrous oxide for nitrogen and oxygen isotopic analysis in freshwater and seawater, Anal. Chem., 77, 5589-5595, 2005.

Michalski, G., Scott, Z., Kabiling, M., and Thiemens, M. H.: First measurements and modeling of $\Delta^{17} \mathrm{O}$ in atmospheric nitrate, Geophys. Res. Lett., 30, 14-11, 2003.

Michalski, G., Meixner, T., Fenn, M., Hernandez, L., Sirulnik, A., Allen, E., and Thiemens, M.: Tracing Atmospheric Nitrate Deposition in a Complex Semiarid Ecosystem Using $\Delta^{17} \mathrm{O}$, Environ. Sci. Tech., 38, 2175-2181, https://doi.org/10.1021/es034980+, 2004.

Michalski, G., Bhattacharya, S. K., and Girsch, G.: NO$x$ cycle and the tropospheric ozone isotope anomaly: an experimental investigation, Atmos. Chem. Phys., 14, 4935-4953, https://doi.org/10.5194/acp-14-4935-2014, 2014.

Morin, S., Savarino, J., Bekki, S., Gong, S., and Bottenheim, J. W.: Signature of Arctic surface ozone depletion events in the isotope anomaly $\left(\Delta^{17} \mathrm{O}\right)$ of atmospheric nitrate, Atmos. Chem. Phys., 7, 1451-1469, https://doi.org/10.5194/acp-7-1451-2007, 2007.

Morin, S., Savarino, J., Frey, M. M., Yan, N., Bekki, S., Bottenheim, J. W., and Martins, J. M. F.: Tracing the origin and fate of $\mathrm{NO}_{x}$ in the arctic atmosphere using stable isotopes in nitrate, Science, 322, 730-732, https://doi.org/10.1126/science.1161910, 2008.

Morin, S., Savarino, J., Frey, M. M., Domine, F., Jacobi, H. W., Kaleschke, L., and Martins, J. M. F.: Comprehensive isotopic composition of atmospheric nitrate in the Atlantic Ocean boundary layer from $65^{\circ} \mathrm{S}$ to $79^{\circ} \mathrm{N}, \mathrm{J}$. Geophys. Res.-Atmos., 114, https://doi.org/10.1029/2008JD010696, D05303, 2009.

Morino, Y., Kondo, Y., Takegawa, N., Miyazaki, Y., Kita, K., Komazaki, Y., Fukuda, M., Miyakawa, T., Moteki, N., and Worsnop, D. R.: Partitioning of $\mathrm{HNO}_{3}$ and particulate nitrate over Tokyo: Effect of vertical mixing, J. Geophys. Res.-Atmos., 111, D15215, https://doi.org/10.1029/2005JD006887, 2006.

Patris, N., Cliff, S. S., Quinn, P. K., Kasem, M., and Thiemens, M. H.: Isotopic analysis of aerosol sulfate and nitrate during ITCT-2k2: Determination of different formation pathways as a function of particle size, J. Geophys. Res.-Atmos., 112, D23301, https://doi.org/10.1029/2005JD006214, 2007.

Proemse, B. C., Mayer, B., Chow, J. C., and Watson, J. G.: Isotopic characterization of nitrate, ammonium and sulfate in stack $\mathrm{PM}_{2.5}$ emissions in the Athabasca Oil Sands Region, Alberta, Canada, Atmos. Environ., 60, 555-563, https://doi.org/10.1016/j.atmosenv.2012.06.046, 2012.

Proemse, B. C., Mayer, B., Fenn, M. E., and Ross, C. S.: A multi-isotope approach for estimating industrial contributions to atmospheric nitrogen deposition in the Athabasca oil sands region in Alberta, Canada, Environ. Pollut., 182, 80-91, https://doi.org/10.1016/j.envpol.2013.07.004, 2013.

Randles, R. H. and Wolfe, D. A.: Introduction to the theory of nonparametric statistics, Wiley, New York, USA, 1979.

Rolph, G. D.; Real-time Environmental Applications and Display sYstem (READY), available at: http://www.ready.noaa.gov, last access: 19 January 2017.

Savard, M. M., Cole, A., Smirnoff, A., and Vet, R.: $\delta^{15} \mathrm{~N}$ values of atmospheric $\mathrm{N}$ species simultaneously collected us- ing sector-based samplers distant from sources - Isotopic inheritance and fractionation, Atmos. Environ., 162, 11-22, https://doi.org/10.1016/j.atmosenv.2017.05.010, 2017.

Savarino, J., Kaiser, J., Morin, S., Sigman, D. M., and Thiemens, M. H.: Nitrogen and oxygen isotopic constraints on the origin of atmospheric nitrate in coastal Antarctica, Atmos. Chem. Phys., 7, 1925-1945, https://doi.org/10.5194/acp-7-1925-2007, 2007.

Savarino, J., Bhattacharya, S. K., Morin, S., Baroni, M., and Doussin, J. F.: The $\mathrm{NO}+\mathrm{O}_{3}$ reaction: A triple oxygen isotope perspective on the reaction dynamics and atmospheric implications for the transfer of the ozone isotope anomaly, J. Chem. Phys., 128, 194303, https://doi.org/10.1063/1.2917581, 2008.

Seinfeld, J. H. and Pandis, S. N.: Atmospheric chemistry and physics, Wiley, Hoboken, NJ, USA, 2006.

Sickles Ii, J. E., Hodson, L. L., McClenny, W. A., Paur, R. J., Ellestad, T. G., Mulik, J. D., Anlauf, K. G., Wiebe, H. A., Mackay, G. I., Schiff, H. I., and Bubacz, D. K.: Field comparison of methods for the measurement of gaseous and particulate contributors to acidic dry deposition, Atmos. Environ. A-Gen., 24, 155-165, https://doi.org/10.1016/0960-1686(90)90451-R, 1990.

Sickles Ii, J. E., Hodson, L. L., and Vorburger, L. M.: Evaluation of the filter pack for long-duration sampling of ambient air, Atmos. Environ., 33, 2187-2202, https://doi.org/10.1016/S13522310(98)00425-7, 1999.

Sirois, A. and Fricke, W.: Regionally representative daily air concentrations of acid-related substances in Canada; 1983-1987, Atmos. Environ. A-Gen., 26, 593-607, https://doi.org/10.1016/0960-1686(92)90172-H, 1992.

Sirois, A. and Vet, R.: The Precision of Precipitation Chemistry Measurements in the Canadian Air and Precipitation Monitoring Network (CAPMoN), Environ. Monit. Assess., 57, 301-329, https://doi.org/10.1023/a:1006035129393, 1999.

Smirnoff, A., Savard, M. M., Vet, R., and Simard, M. C.: Nitrogen and triple oxygen isotopes in near-road air samples using chemical conversion and thermal decomposition, Rapid Commun. Mass Sp., 26, 2791-2804, https://doi.org/10.1002/rcm.6406, 2012.

Spicer, C. W., Howes Jr., J. E., Bishop, T. A., Arnold, L. H., and Stevens, R. K.: Nitric acid measurement methods: An intercomparison, Atmos. Environ., 16, 1487-1500, https://doi.org/10.1016/0004-6981(82)90071-3, 1982.

Stein, A., Draxler, R., Rolph, G., Stunder, B., Cohen, M., and Ngan, F.: NOAA's HYSPLIT atmospheric transport and dispersion modeling system, B. Am. Meteorol. Soc., 96, 2059-2077, 2015.

Stroud, C. A., Abbatt, J., Leiming, Z., Flagg, D., and Makar, P.: Atmospheric processes, chap. 2 - Draft version, in: Canadian smow Science Assessment, Environment Canada publisher, Ottawa, Ontario, Canada, 2008.

Thiemens, M. H.: Mass-independent isotope effects in planetary atmospheres and the early solar system, Science, 283, 341-345, https://doi.org/10.1126/science.283.5400.341, 1999.

Tsunogai, U., Komatsu, D. D., Daita, S., Kazemi, G. A., Nakagawa, F., Noguchi, I., and Zhang, J.: Tracing the fate of atmospheric nitrate deposited onto a forest ecosystem in Eastern Asia using $\Delta^{17} \mathrm{O}$, Atmos. Chem. Phys., 10, 1809-1820, https://doi.org/10.5194/acp-10-1809-2010, 2010.

Vicars, W. C. and Savarino, J.: Quantitative constraints on the $17 \mathrm{O}$-excess $\left(\Delta^{17} \mathrm{O}\right)$ signature of surface ozone: Ambient 
measurements from $50^{\circ} \mathrm{N}$ to $50^{\circ} \mathrm{S}$ using the nitrite-coated filter technique, Geochim. Cosmochim. Ac., 135, 270-287, https://doi.org/10.1016/j.gca.2014.03.023, 2014.

Vicars, W. C., Bhattacharya, S. K., Erbland, J., and Savarino, J.: Measurement of the ${ }^{17} \mathrm{O}$-excess $\left(\Delta^{17} \mathrm{O}\right)$ of tropospheric ozone using a nitrite-coated filter, Rapid Commun. Mass Sp., 26, 12191231, https://doi.org/10.1002/rcm.6218, 2012.

Vicars, W. C., Morin, S., Savarino, J., Wagner, N. L., Erbland, J., Vince, E., Martins, J. M. F., Lerner, B. M., Quinn, P. K., Coffman, D. J., Williams, E. J., and Brown, S. S.: Spatial and diurnal variability in reactive nitrogen oxide chemistry as reflected in the isotopic composition of atmospheric nitrate: Results from the CalNex 2010 field study, J. Geophys. Res.-Atmos., 118, 1056710588, https://doi.org/10.1002/jgrd.50680, 2013.
Wang, X. L., Watson, J. G., Chow, J. C., Kohl, S. D., Chen, L. W. A., Sodeman, D. A., Legge, A. H., and Percy, K. E.: Measurement of Real-World Stack Emissions with a Dilution Sampling System, Dev. Environm. Sci., 171-192, 2012.

Zel'dovich, Y. B.: The Oxidation of Nitrogen in Combustion and Explosions, Acta Physicochimica, 21, 577-628, 1946.

Zhang, L., Vet, R., O’Brien, J. M., Mihele, C., Liang, Z., and Wiebe, A.: Dry deposition of individual nitrogen species at eight Canadian rural sites, J. Geophys. Res.-Atmos., 114, D02301, https://doi.org/10.1029/2008JD010640, 2009. 